No $2013-30$

September

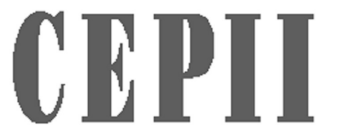

CENTRE

D'ÉTUDES PROSPECTIVES

ET D'INFORMATIONS

INTERNATIONALES

The determinants of international mobility of students

Michel Beine, Romain Noël and Lionel Ragot 


\section{TABLE OF CONTENTS}

Highlights and Abstract. . . . . . . . . . . . . . . . . . . . . . . . . . . 3

Points clefs et résumé. . . . . . . . . . . . . . . . . . . . . . . . . . . . 4

1. Introduction . . . . . . . . . . . . . . . . . . . . . . . . 5

2. Descriptive evidence and literature . . . . . . . . . . . . . . . . . . . 8

2.1. Some stylized facts . . . . . . . . . . . . . . . . . . . . . . . . . 8

2.2. Related literature . . . . . . . . . . . . . . . . . . . . . . . 13

3. Theoretical background . . . . . . . . . . . . . . . . . . . 14

4. Data . . . . . . . . . . . . . . . . . . . . . . . . 17

4.1. International students versus foreign students . . . . . . . . . . . . . . . 17

4.2. Other data . . . . . . . . . . . . . . . . . . . . . . . . . . . . . 18

5. Measuring determinants of student's migration . . . . . . . . . . . . . . . . 21

5.1. Econometric approach . . . . . . . . . . . . . . . . . . . . . . . . 21

5.2. Results . . . . . . . . . . . . . . . . . . . . . . . . . . . . . 22

6. Conclusion and discussion . . . . . . . . . . . . . . . . . . . . . . . . 32

Appendix . . . . . . . . . . . . . . . . . . . . . . . . . . 37 


\title{
THE DETERMINANTS OF INTERNATIONAL MOBILITY OF STUDENTS
}

Michel Beine, Romain Noël and Lionel Ragot

\section{HighLightS}

- The number of students who study abroad has been multiplied by a factor of 4 between 1975 and 2008.

- The factors measuring the costs of migration are statistically significant and economically meaningful.

- We find a strong network effect which is increasing with the level of education of the network at destination.

- Students, in their location choice, are sensitive to the wage and to the quality of higher education at destination, to the living costs and host capacity.

- An attractiveness policy should pay special attention to reducing the costs at destination, and is all the more effective when it reduces the living costs rather than the fees.

\begin{abstract}
This paper analyzes the determinants of the choice of location of international students. Building on the documented trends in international migration of students, we develop a small theoretical model allowing to identify the various factors associated to the attraction of migrants as well as the costs of moving abroad. Using new data capturing the number of students from a large set of origin countries studying in a set of 13 OECD countries, we assess the importance of the various factors identified in the theory. We find support for a significant network effect in the migration of students, a result so far undocumented in the literature. We also find a significant role for cost factors such as housing prices and for attractiveness variables such as the reported quality of universities. In contrast, we do not find an important role for registration fees (reverse causality, signal of quality, covered by grants).
\end{abstract}

JEL Classification: F22, O15

Keywords: $\quad$ student mobility, network effect, migration costs, attractiveness policy. 


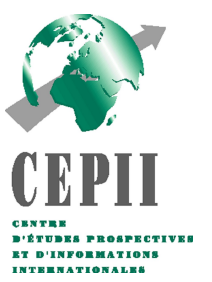

\section{LES DÉTERMINANTS DE LA MOBILITÉ INTERNATIONALE DES ÉTUDIANTS}

Michel Beine, Romain Noël et Lionel Ragot

\section{Points Clefs}

- Le nombre d'étudiants en mobilité internationale a été multiplié par 4 entre 1975 et 2008.

- Nous trouvons un effet de réseau significatif, croissant avec le niveau de qualification.

- Les étudiants sont sensibles aux salaires, à la qualité de l'enseignement supérieur, aux capacités d'accueil et au coût de la vie.

- Nous montrons que dans le cadre d'une politique d'attractivité des étudiants les pouvoirs publics doivent chercher à réduire les coûts de la vie plutôt que les frais d'inscription.

\section{RÉSUMÉ}

Dans ce papier nous estimons les déterminants des choix de localisation des étudiants en mobilité internationale. Un petit modèle théorique, inspiré des principaux faits stylisés de cette mobilité, met en avant les différents facteurs (coûts de cette migration et variables d'attractivité spécifique des pays de destination) influençant le comportement de localisation des étudiants en mobilité. À partir d'une base de données récente de l'OCDE répertoriant l'ensemble des flux bilatéraux d'étudiants entre plus de 200 pays d'origine vers 13 pays de l'OCDE, nous estimons l'importance de chacun des facteurs identifiés par le modèle théorique. Nous mettons en évidence un effet réseau relativement important dans la migration des étudiants, effet qui n'avait pas été mis en avant jusqu'à présent dans la littérature existante. Des facteurs de coûts, tel que le coût de la vie (logement plus nourriture) et des facteurs d'attracivité spécifiques, tel que la qualité du système d'enseignement supérieur, expliquent ces choix de localisation géographique. Par contre, notre étude montre que les droits d'inscription ont peu d'influence sur ces choix, avec un coefficent de signe positif quand il est significatif. Nous avançons plusieurs interprétations économiques à ce dernier résultat : endogénéité, effet signal, importance des bourses.

Classification JEL : F22, O15

Mots clés : mobilité internationale des étudiants, effets réseaux, coûts de la migration, politiques d'attractivité des étudiants 


\title{
THE DETERMINANTS OF INTERNATIONAL MOBILITY OF STUDENTS ${ }^{1}$
}

\author{
Michel Beine*, Romain Noël ${ }^{\dagger}$ and Lionel Ragot ${ }^{\ddagger}$
}

\section{INTRODUCTION}

Globalization of higher education, through mobility of students, has grown considerably over the past 40 years. The number of students who study abroad has been steadily rising since 1970's. It has been multiplied by a factor of 4 between 1975 and 2008. Among the various categories of migrants, international students are the ones who have experienced the most rapid increase in relative terms.

Developed countries are highly interested in attracting foreign students for several reasons. First, foreign students represent an important source of income for universities. In a lot of OECD countries, institutions providing higher education face adverse domestic demographic trends in terms of number of potential students. By attracting foreign students, for instance from populous countries, they relax the demographic binding constraints related to the domestic market. Furthermore, in some countries, international students tend to pay higher fees compared to domestic students. ${ }^{2}$ This allows to circumvent some of the legal constraints faced by public institutions in terms of registration conditions, including fees. Second, colonial powers have always favored the migration of students from former colonies as part of the global package of foreign aid. Higher education provided to foreign students is one important channel allowing host countries to diffuse cultural, economic and political norms abroad. For instance, Spilimbergo (2009) shows that foreign education promotes democracy in the origin countries of the students, especially when education has been acquired in democratic countries.

Third and maybe more importantly, the international mobility of students is highly related to another form of migration, the one concerning skilled and highly skilled workers. Unlike other

\footnotetext{
${ }^{1}$ This paper has benefitted from comments and suggestions of participants of seminars and conferences held in Bari, Paris (Cepii, OECD) and Brussels (University Foundation). We thank in particular Simone Bertoli, Cossimo Beverelli, Brian Burgoon, Nicola Coniglio, Serge Coulombe, Patrick Gaulè, Benedikt Heid, Hubert Jayet, Thierry Mayer, Alireza Naghavi, Caglar Ozden, Maurice Schiff, Eiko Thielemann and Farid Toubal for helpful comments and suggestions. All errors remain our own.

*University of Luxemburg

${ }^{\dagger}$ Equippe, University of Lille 1

${ }^{\ddagger}$ CEPII, Economix, University of Paris Ouest (lionel.ragot@ cepii.fr)

${ }^{2}$ For instance, it is the case in the UK where British universities are worrying about the loss of public funding they could be subjected to, following the willingness of the government to reduce the number of foreign students by half by 2015. Indeed, fees paid by overseas students are very higher than fees paid by natives or EU members.
} 
forms of migration (forced migration, low skilled workers, family reunification), the migration of skilled workers (the so called brain drain phenomenon) has been part of the worldwide process of globalization (Docquier and Rapoport (2011)). It reflects the growing interest of countries to attract talents and skills needed to spur their growth process. International students are likely to stay and work in the host country once they have completed their studies (Rosenzweig (2008)). ${ }^{3}$ They represent therefore a potential valuable source of educated labor force for countries providing higher education, especially because they became familiar with the customs and the culture of the country while studying. It is not therefore surprising that some countries have explicitly implemented policies favoring the integration of foreign students in the labor market. ${ }^{4}$

Of course, international mobility of students is also an important phenomenon for sending countries. Those countries are both developed and developing countries. The emigration of agents for the explicit purpose of acquiring skills and human capital is therefore highly related to the brain drain and brain gain phenomenon. As identified in the recent literature (see among others Docquier and Rapoport (2011), Beine et al. (2008)), perspectives of emigration of workers induce two effects. The first one is the depletion of the existing human capital stock in the origin country, the so-called brain drain effect. The second one is more subtle and is reflected by an incentive effect for uneducated agents to educate to take profit of higher returns of education abroad; this is the brain gain effect. Possibilities for student to study abroad are also expected to generate both effects, although their relative magnitude is hard to guess. There is a clear brain drain effect since as said before, some foreign students will become permanent migrants in the countries where they got their education. Nevertheless, there is also a clear brain gain effect, at least for two joint reasons. The first one is that some skills cannot be acquired at origin. For instance, there are many countries in which there is no medical school or engineer education

\footnotetext{
${ }^{3}$ In Australia, about $18.7 \%$ of all foreign graduates remained in the country in 2002. In Canada, between $15 \%$ and $20 \%$ of international students can be expected to establish and work in the country. $27 \%$ of foreign graduates from a UK institution of the academic year 2004/05 were employed in the United Kingdom. In the USA, 23\% of persons with an H-1B visa are estimated to have had prior student visa (OECD (2009b)). Former international students represented, in 2007, 68\% of permanent labor migration in France. Despite the fact that data is not available for all countries, OECD (2009a) expected that stay rates of foreign students is between 15 and $35 \%$ for most countries. The stay rates of students having a PhD in the United States seem to be higher. According to Finn (2003), the stay rate after two years is about 70\% in 1999 with strong disparities across fields of study (from 75\% in physical and computers sciences and engineering to $45 \%$ in economics and agricultural sciences). Rosenzweig (2008) shows that the differences in skill prices between the origin and destination countries is a major determinant of stay rates of students.

${ }^{4}$ This is for instance illustrated by the recent policy debate about student visa policy in the UK. To quote Damian Green, the Immigration Minister of the United Kingdom (The Guardian, Tuesday 1 February 2011): "I believe attracting talented students from abroad is vital to the UK, but we must be more selective about who can come here and how long they can stay". The UK is indeed about to review its immigration policies concerning overseas students (those outside the European economic area) and wants to reduce the number of overseas students from 200000 to fewer than 100000 by 2015. According to the Immigration office, two-thirds of the non-EU migrants who enter the UK come on student visas and the government wants to redefine the post-study access to the labor market. Only those graduating with a job offer already in hand will be authorized to stay in the UK.
} 
program. In that case, going abroad does not reduce this particular form of human capital. The second reason is that as documented by many studies, education quality for the same degree is not the same across countries (see for instance Hanushek and Hanson (2000)). A subset of foreign students come back in their country of origin, with a better education level that the one they would have got had they studied at home. This has in turn major implications for growth perspectives of these countries.

Policies in destination countries concerned with the management of international students can act on two complementary grounds. First, policy can focus on the attraction of foreign students. Second, one can attempt to influence the retention of students, once they have graduated to ensure a highly-skilled workforce. With respect to the attraction of international students, OECD countries tend to consider various solutions. Countries can be quite liberal in issuing student visas compared to other types of visas. They can regulate tuition fees. Alternatively, policy can aim at lowering some costs such as housing expenses through subsidies. They can also offer English-language courses, facilitate the credit transfers between universities and allow the part-time work while studying. This last policy allows students to cover part of the costs they have to support and also to acquire some specific knowledge of the local job market. ${ }^{5}$

The identification of the key determinants of international student mobility is central to design efficient policies aimed at attracting foreign students. Those determinants pertain both to origin and destination countries. Focusing on the migration of foreign students to the US, Rosenzweig (2008) looks at the determinants in the origin countries. He shows that among many factors, the provision of undergraduate higher education and the low level of skill prices in the origin countries tend to favor emigration of students. Low skill prices at origin also increase the stay rates of students once they have completed their education in the US. Bessey (2007) provides a similar analysis for Germany. In contrast, the literature is so far much more silent on the identification of the key factors at destination influencing the location of students (pull factors). By analyzing international student mobility in a multi-origin and multi-destination framework, this paper contributes to the identification of the key determinants at destination. ${ }^{6}$ In turn, this identification allows to shed some light of the potential policies that can be implemented by countries willing to attract more foreign students. We first develop a simple theoretical model capturing the main driving forces for students keen to study abroad. Those forces include the costs and attractiveness of foreign education. Then using new OECD data on students in mobility, we assess the impact of the various key variables on the dyadic flows of students.

Our paper is related to previous studies devoted to international student migration. First, com-

\footnotetext{
${ }^{5}$ For example, in France, international students can work while studying without work authorization provided employment does not exceed $60 \%$ of their total annual workload. Norway allows students to work 20 hours a week. In Luxembourg, first-year students may apply for a work permit if their paid employment is within the University. Other students may work outside the university and the permit of work is renewable if the student re-registers in the university. The permit may be withdrawn if the student does not attend classes on a regular basis.

${ }^{6}$ See also Perkins and Neumayer (2012) for a recent similar approach.
} 
pared to Rosenzweig $(2008,2006)$ who focus on student migration in the US, our analysis integrates a set of alternative destinations. The 13 OECD destinations that are covered in our sample represent more or less $75 \%$ of the flows of international students, compared to $20 \%$ for the US. It allows to capture the substitution and the relative attractiveness between alternative destinations, a key feature for designing policies at destination. While the literature devoted to student migration is quite limited, our paper is obviously related to a large literature devoted to the explanation of international migration flows. There is an extensive and fast growing literature on international migration. Our paper is specifically tied to the macroeconomic analyzes combining a large set of origin and destination countries, including the recent works of Beine et al. (2011) and Grogger and Hanson (2011).

The paper is organized as follows. Section 2 describes the trends in migration of foreign students in the OECD countries and reviews the relevant literature. Section 3 presents a simple theoretical framework allowing to identify the important determinants. Section 4 presents the data necessary to estimate the determinants of the choice of location of international students. Key data captures the flows of students in mobility, i.e, students who migrated explicitly for educational purposes. The data is available annually for 13 OECD countries and for students coming from 216 origin countries from 2004 to 2007. Additional specific destination countries variables were collected to capture quality in higher education systems and costs supported by students. Section 5 presents the econometric approach and exposes the results. Two important results emerge from the estimations. We find a strong network effect, which has not been reported in the literature so far and we show that this effect is stronger for the skilled diaspora. Regarding destination specific features, the quality of universities is a significant magnet for foreign students whereas living costs in the destination country play a deterrent effect. The level of tuition fees does not seem to play a significant role. Section 6 concludes.

\section{DESCRIPTIVE EVIDENCE AND LITERATURE}

\subsection{Some stylized facts}

In 2008, more than 3.3 million students were enrolled in a country from which they were not citizens, including 2.7 million in OECD countries. ${ }^{7}$ This number has been multiplied by 4 between 1975 and 2008. This growth accelerated over the recent period with a rise of $70 \%$, between 2000 and 2008, which corresponds to an average annual growth rate of $9 \%$ (cf. figure $1)$.

\footnotetext{
${ }^{7}$ We distinguish foreign students from international students in the analysis. Foreign students are students who are not citizens of the reporting country whereas international students are those who migrate for the specific aim of completing their education. Because all OECD countries do not report data on international students, figures exposed in this section refer both to foreign and international students and are called foreign students. For more information on the definition, see section 4 .
} 


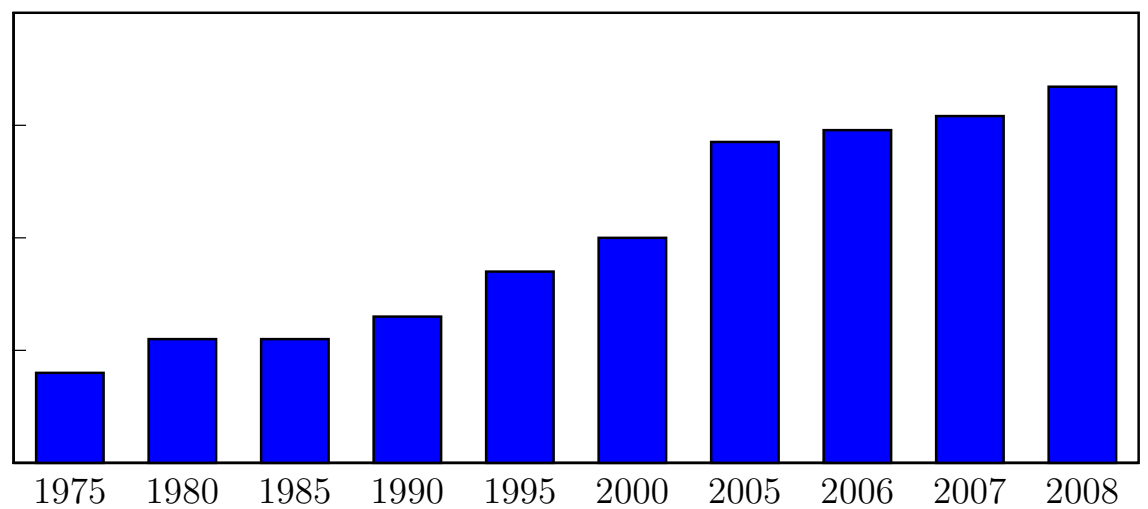

Figure 1 - Students enrolled outside their country of citizenship (million, source: OECD, 2010)

In 2008, Asian students formed the largest group, accounting for nearly half of the total (49.9\%). Asian students are followed by the Europeans with $23.0 \%$ and by students from Africa (11.6\%). South American and North American students only account for $6.0 \%$ and $3.1 \%$ of the total aggregate flows (see Figure 2 and Table 7 in appendix). This distribution is essentially unchanged if we restrict the geographic area of destination to OECD countries, with respectively $48.9 \%$, $24.5 \%, 10.1 \%, 5.3 \%$ and $3.7 \%$ of total flows. We compare the distribution of the geographic origin of international students with the one of continents in the world population (respectively $60.4 \%, 10.8 \%, 14.6 \%, 8.6 \%$ and $5.1 \%$ ). The figures reflect the strong mobility of European students. Except for Europe, the distribution in terms of origins is relatively proportional to the share in the world population.

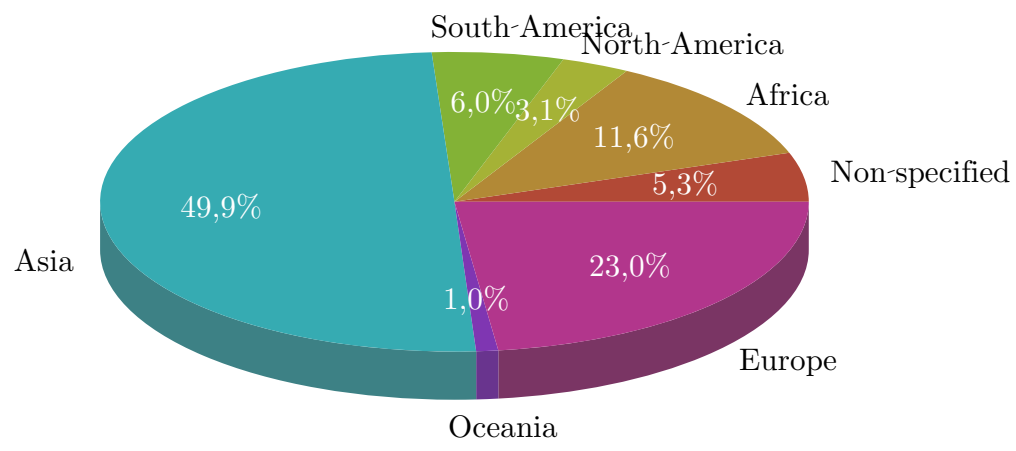

Figure 2 - Distribution of foreign students by geographic region of origin, 2008 (source: OECD, 2010)

Since 2005, there has been a larger increase of students moving to non-OECD countries compared to those going to an OECD country (20.8\% of total flows in 2008 against $16.8 \%$ in 2005). A refined analysis of this geographic distribution of foreign students flows (cf. Figure 3) suggests a high concentration in terms of destinations. About $50 \%$ go only to five countries: the 
United States, the United Kingdom, Germany, France and Australia. More than $83.4 \%$ of the total of foreign students enrolled worldwide are concentrated in OECD countries.

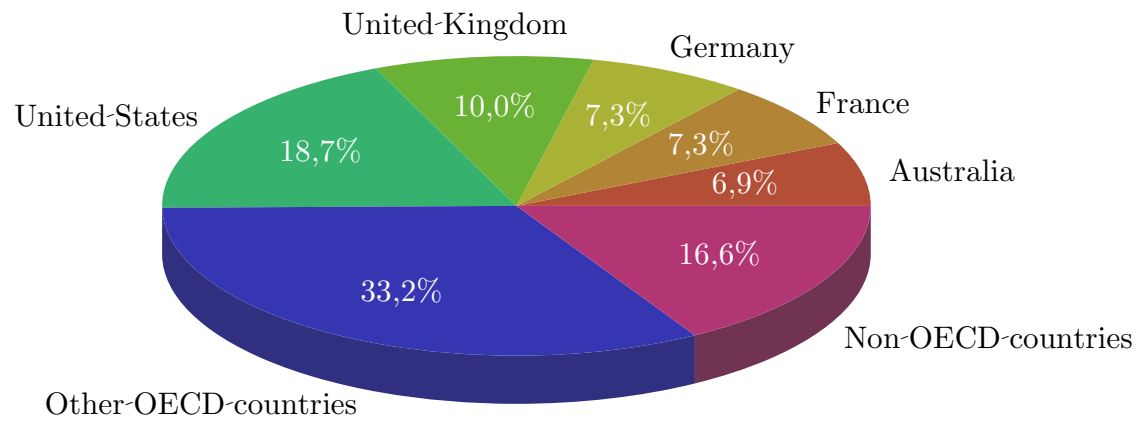

Figure 3 - Distribution of foreign students by geographic region of destination, 2008 (source: OECD, 2010)

Figures 4, 5, 6 and 7 highlight the differences in foreign students' origins in 4 of these 5 main countries of destination. It is interesting to notice that a majority of countries (about 75\%) send less than 500 (or less than 1500 for US) students to those four destinations, in 2008.

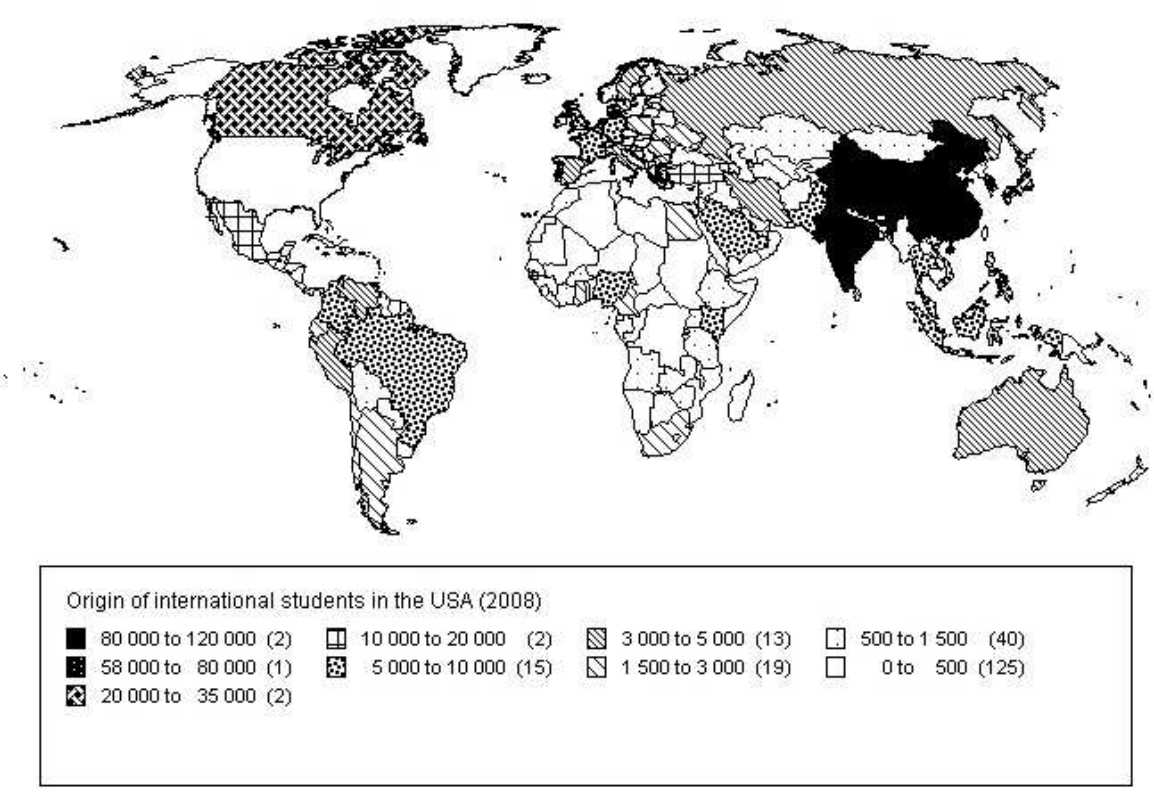

Figure 4 - United States: origin of international students (2008) 


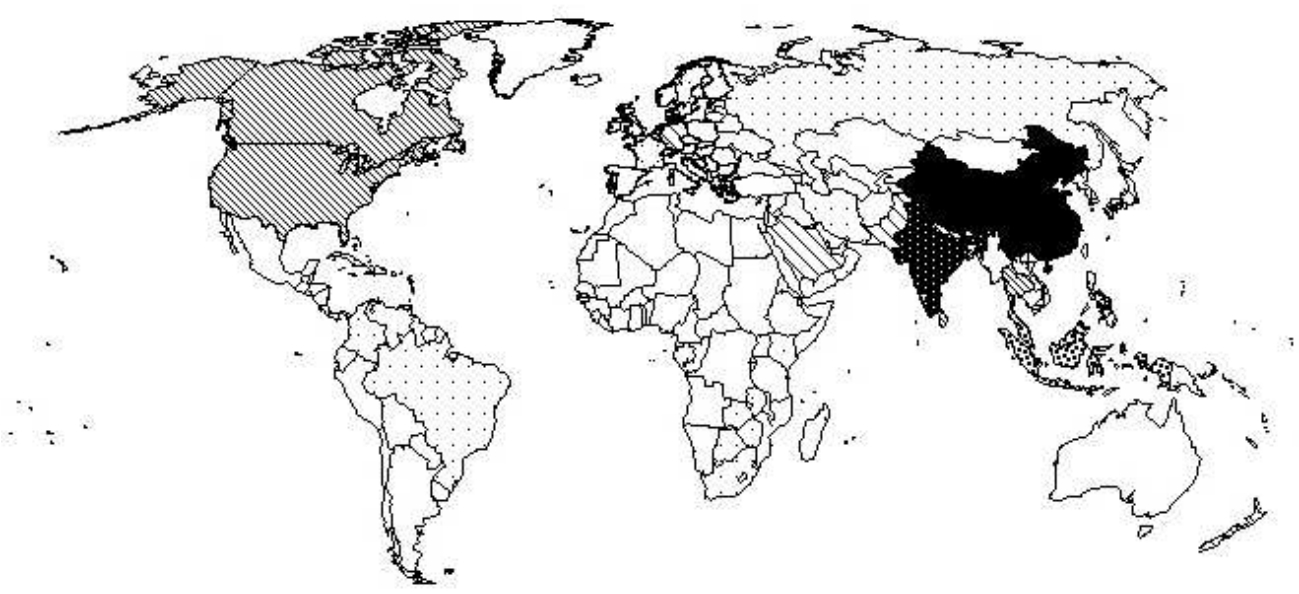

Origin of international students in Australia (2008)

35000 to 58000 (1) 10000 to 20000 (3) 3000 to 5000 (5) 口500 to 1500 (20)

20000 to 35000 (1) 口 5000 to 10000 (3) $\bigotimes 1500$ to 3000 (7) $\square \quad 0$ to 500 (179)

Figure 5 - Australia: origin of international students (2008)

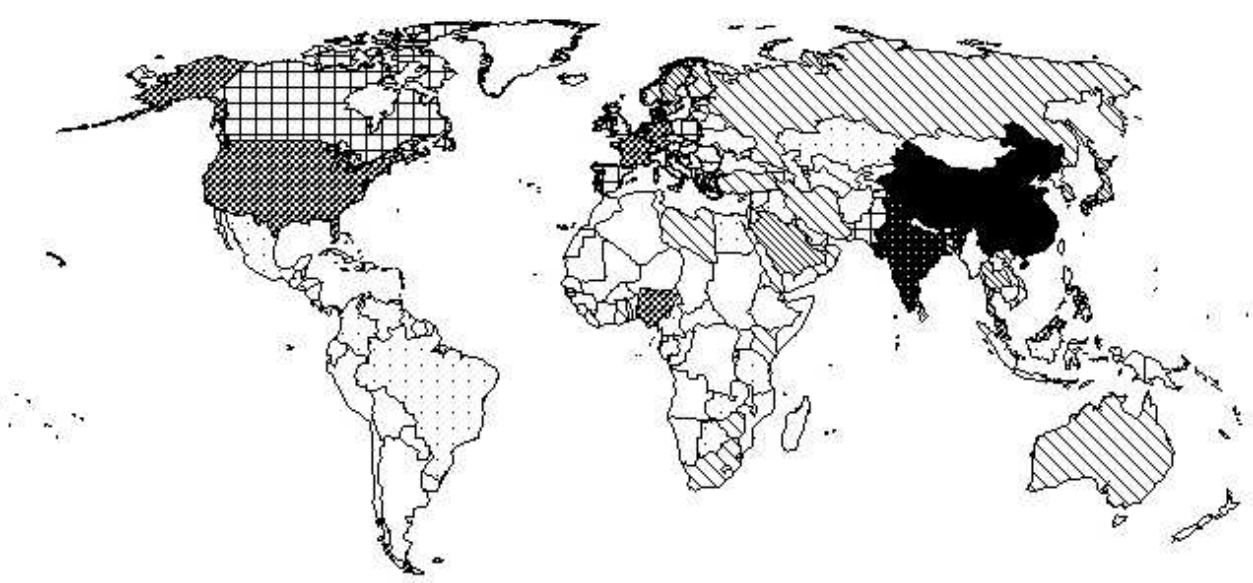

Origin of international students in the UK (2008)

35000 to 58000 (1) 叉 10000 to 20000 (7) $\mathbb{Q} 3000$ to 5000 (7) $\square 500$ to 1500 (36)

20000 to 35000 (1) $\boxplus 5000$ to $10000(7) \quad \triangle 1500$ to $3000(23) \quad \square \quad 0$ to $500(137)$

Figure 6 - United-Kingdom: origin of international students (2008) 


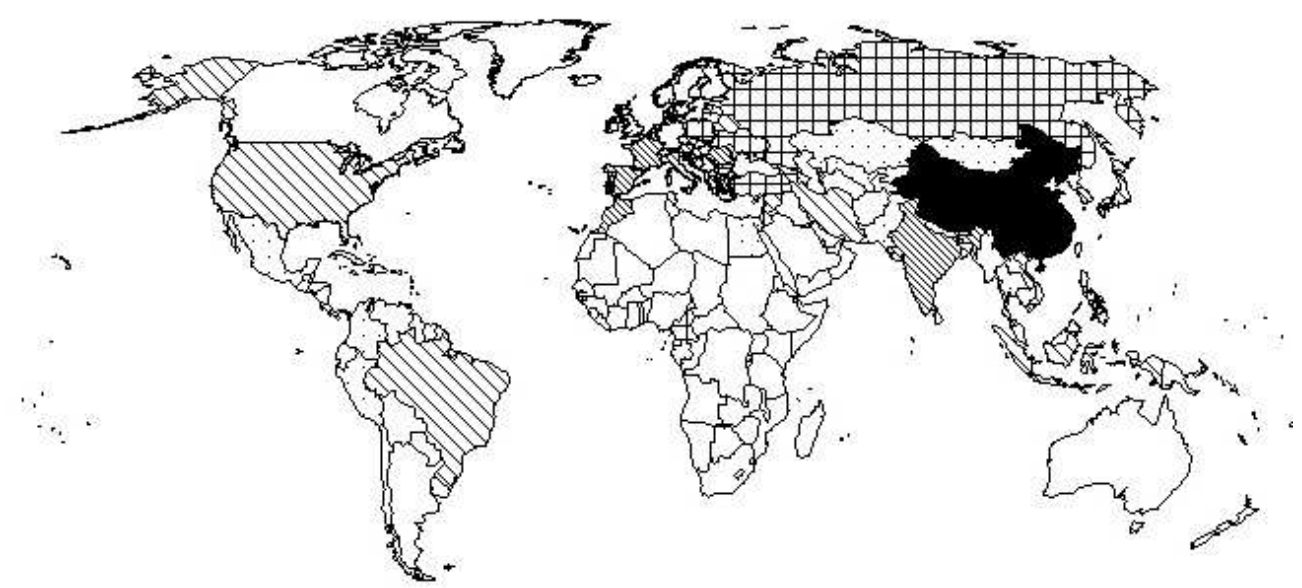

$$
\begin{aligned}
& \text { Origin of international students in Germany (2008) } \\
& \begin{array}{r}
20000 \text { to } 35000(1) \quad \mathbb{3} 3000 \text { to } 5000 \quad(8) \quad \square \quad \square 00 \text { to } 1500 \quad(24) \\
\quad \square 000 \text { to } 10000(6) \quad \square \quad 1500 \text { to } 3000(15) \quad \square \quad 0 \text { to } 500 \text { (165) }
\end{array}
\end{aligned}
$$

Figure 7 - Germany: origin of international students (2008)

Students from Asia make up a significant proportion of the total number of foreign students in Australia and United States (respectively $79 \%$ and $67 \%$, see Table 7 in appendix). China is the first sending country for those four destinations. Russia, Turkey and other European countries are second sending countries, after China, to Germany.

The share of foreign students in total enrollment in OECD receiving countries is also of interest. Figures observed for the year 2007 reveal strong disparities. Thus, although the United States was the first destination for 595900 international students, the share of these students in total enrollment $(3,4 \%)$ is twice below the OECD average (7.1\%). New Zealand and Switzerland received fewer international students (about 30000 ) in absolute terms but quite a lot in relative terms, i.e. respectively $13.6 \%$ and $14 \%$ (see Table 8 in appendix).

In 2007, the size of the flow of international students was comparable to the flows of foreign workers for Austria and Belgium (see Table 8 in appendix). Australia, Japan, New Zealand and the United Kingdom received more international students than foreign workers. In contrast, Canada, Switzerland, Germany and the United States received less students than they received foreign workers. Moreover, the share of international students in the total enrollment in tertiary education is lower than the share of foreign-born workers in the active population in every country except for Switzerland and the United Kingdom. 


\subsection{Related literature}

Two main reasons have been advanced in the literature to explain the migration of students between countries or regions. First, from a human capital perspective, migration is considered as an investment and the decision to move is made to grab better job opportunities and/or to increase the future expected income. Second, migration can also be viewed as a consumption choice. In that case, people move for non-pecuniary reasons. Students not only focus on the returns of higher education in the future, but also take into account the context in which they will study.

In the human capital perspective, Rosenzweig (2006) proposes two models to explain the international mobility of students to developed countries. First, migration takes place because of a lack of educational facilities in the home country regardless the level of education returns (school-constrained model). In that case, students migrate to acquire human capital and return home to reap the benefits of education investment at origin. Second, migration under a student visa could be a mean to enter and stay in a foreign country to escape low returns in education in the origin country. The quest for higher income is the main determinant of student migrations in this so called migration model. Those two models are competing in terms of predictions and implications. In the school-constrained model, an increase in the return from education in the home country leads more students to study abroad, whereas, in the migration model, it rather tends to reduce the flows of students. Moreover, other things being equal, if the quality and the quantity of schools increase, the number of students who seek education abroad will be reduced in the school-constrained model, but the outflows of students in the migration model will increase. The study of the flows of foreign students from a large set of countries (125 countries) to the United States suggests that students come to the US and stay when the returns to education are low in their country of origin. Then, the gap in wages between the US and developing countries motivates people to study abroad. Those results are confirmed by Rosenzweig (2008). The United States is an attractive destination for international students due to the skill premium paid in the labor market and due to the large number of US universities. Finally, mobility of students can be explained by the same determinants that for migrations of workers including higher wages.

The return rates of foreign students is a key issue analyzed by Rosenzweig (2008). Return rates of foreign students from the US are higher for countries with higher skill prices. Bratsberg (1995) shows that if educational attainment of a foreign student exceeds the average education level in the home country or if the return to education in the home country is higher, the student is less likely to stay in the United States. Moreover, the composition of students who remain in the US is a function of the skill price differential between the home country and the US.

Haupt et al. (2010) deal with migrations of students from the perspective of brain gain and show that brain drain cannot be only due to individuals from developing countries incentives to acquire human capital but also by incentives in the rich countries to improve their education policy. The need for host countries to retain foreign students indeed leads them to increase the 
quality of their educational system in order to benefit from the externalities of human capital accumulation. It enhances the human capital of all students, included those who return home. Then, it can generate a brain gain. International mobility of students and its effects have also been studied by Dreher and Poutvaara (2005) where a positive correlation between flows of students and international migration as a whole is found. Borjas (2004) presents two possible crowding-out effects for native students due to arrivals of foreign students.

Other empirical works discuss the motivations and determinants of students in mobility. Those studies concern either international mobility of students or internal mobility, i.e mobility of students between regions or states within a country. They often evaluate the determinants by an augmented gravity equation where data describing amenities are introduced in addition to the traditional determinants such as distance, GDP and population. Distance always plays a deterrent effect but the effect of GDP is more ambiguous. Concerning international migration, Bessey (2007) studies the flows of international students to Germany. The stock of foreign students of a nationality, in the destination country, and the flows of students with the same nationality seem positively correlated. This analysis does not however include variables characterizing the quality of higher education. Some survey analysis which cover the prospective international students as unit of analysis reveal that the discrepancy in education quality between a foreign degree and a domestic one is one of the main motivations for students to go overseas (Gordon and Jallade (1996); Aslangbengui and Montecinos (1998); Szelenyi (2006)).

Van Bouwel (2009) introduces two different measures of quality of education: the relative impact of a country's publications relative to the share of a country's citations in world publications and the number of national universities within the top 200 of the Shanghai ranking. Both quality indicators have a positive impact on the size and direction of students flows. The Shanghai ranking has also been used by Thissen and Ederveen (2006). Other components of higher education system such as educational opportunities or government spending on higher education have been used by Cummings (1984) and McMahon (1992).

Papers on internal migration of students within a country are also useful as references. They either use individuals as unit of analysis (Ono (2001); McCann and Sheppard (2001); Kjellstrom and Regner (1998)) or use place-to-place data or data specific to institutions (Mixon and Hsing (1994a,b); Baryla and Dotterweich (2001)) or aggregate data about states or regions (Mixon (1992a,b); Sa et al. (2004); Agasisti and Dal Bianco (2007)).

\section{THEORETICAL BACKGROUND}

This section derives a tractable students' migration equation from a simple theoretical model based on the human capital literature. Education is considered as an investment in future earnings and employment (see Becker (1964)) for rational students who seek to maximize their lifetime earnings. The quality of education may affect their expected returns to education (Card and Krueger (1992)). The prospective student migrant compares the present value of future earnings if he/she decides to study at home to the one obtained from studying abroad. If the 
increase in the present value of the future income is greater than the cost of migrating as well as other education costs, students will move to the country yielding the highest net present value. However studying at home does not rule out to migrate after graduation for the sake of working in another country. Similarly, studying abroad facilitates access to the local labor market, but does not preclude the possibility of returning home or migrating, after graduation, to a third country. Student's location decisions before and after education are not independent but are taken sequentially; first the educational location and then the working location. Students form (myopic) expectations about future income by observing the current skill prices (Freeman (1971)) and the working migrations probabilities. The relevant probabilities are (i) the probability to migrate, once the studies at home are completed; (ii) the probability of getting a job in the destination country in which schooling has been obtained; (iii) the probability of return migration and (iv) the probability to migrate to a third country.

The utility of a student is linear in income and depends on migrations costs, educationnal costs and some characteristics (attractiveness) of destination country. Consistent with this approach based on human capital theory, the utility of a student born in country $i \in O$ and studying in country $i \in O$ (at home) might be expressed as:

$$
u_{i i}=P_{i}^{S} W_{i}+\left(1-P_{i}^{S}\right)\left(\bar{W}+S\left(Q_{i}-\bar{Q}\right)\right)-C E_{i}+\varepsilon_{i}
$$

where $O=1, \ldots, o$ is the set of origin countries with $o$ the number of origin countries, $C E_{i}$ denotes the tertiary educational costs in country $i, P_{i}^{s}$ is the probability of stay and work in country $i$ after graduation in the same country, $W_{i}$ is the expected present value of future earnings if working in country $i, \bar{W}$ the expected present value of future earnings based on the average (developed countries) skill prices, $S($.$) a premium which depends on the difference between$ the quality of education where the higher education has been attained $\left(Q_{i}\right)$ and the quality of education in the working country which is given by the average quality of education abroad $\bar{Q}{ }^{8}$ $\varepsilon_{i}$ is a iid extreme-value distributed random term.

The utility of studying abroad, in country $j \in D$ with $i \neq j$ can be expressed as:

$$
u_{i j}=P^{f} W_{j}+P^{r}\left(W_{i}+S\left(Q_{j}-Q_{i}\right)\right)+\left(1-P^{f}-P^{r}\right)\left(\bar{W}+S\left(Q_{j}-\bar{Q}\right)\right)+A_{j}-C E_{j}-C M_{i j}+\varepsilon_{j}
$$

where $D=1, \ldots, d$ is the set of destination countries with $d$ the number of destination countries; $C M_{i j}$ captures the cost of migrating for a student who decides to move in country $j$ to complete his education and $C E_{j}$ the educational costs in country $j . A_{j}$ includes destination specific

\footnotetext{
${ }^{8}$ By definition, this premium is not taken into account when the educational country will also be the working country. It can be negative if the difference in quality is negative.
} 
variables that affect the attractiveness of country $j$ such as host capacity, living costs. $P^{f}$ is the probability of staying in the destination country and $P^{r}$ the return probability after graduation. We assume that $P^{f}$ and $P^{r}$ are not country specific. ${ }^{9}$

Following the random utility approach to discrete choice problems (McFadden (1981)) and assuming that the hypothesis of irrelevant alternatives holds, the probability that student from country $i$ chooses foreign country $j \in D$ to attain higher education is defined by:

$$
\begin{aligned}
P_{i j} & =\operatorname{Pr}\left\{u_{i j}=\max _{l \in D} u_{i l}\right\} \\
& =\operatorname{Pr}\left\{u_{i j}>u_{i l}, \forall l \neq j \in D\right\} \\
& =\frac{\exp \left[P^{f} W_{j}+P^{r}\left(W_{i}+S\left(Q_{j}-Q_{i}\right)\right)+\left(1-P^{f}-P^{r}\right)\left(\bar{W}+S\left(Q_{j}-\bar{Q}\right)\right)+A_{j}-C E_{j}-C M_{i j}\right]}{\sum_{l \in D} \exp \left[P^{f} W_{l}+P^{r}\left(W_{i}+S\left(Q_{l}-Q_{i}\right)\right)+\left(1-P^{f}-P^{r}\right)\left(\bar{W}+S\left(Q_{l}-\bar{Q}\right)\right)+A_{l}-C E_{l}-C M_{i l}\right]} \\
& =\frac{N_{i j}}{N_{i}}
\end{aligned}
$$

with $N_{i j}$ is the number of students from country $i$ studying in country $j$ and $N_{i}$ the total number of students born in country $i$.

Furthermore, the ratio $N_{i j} / N_{i i}$, where $N_{i i}$ is the number of students from country $i$ studying at home, is given by the following expression:

$$
\frac{N_{i j}}{N_{i i}}=\frac{\exp \left[P^{f} W_{j}+P^{r}\left(W_{i}+S\left(Q_{j}-Q_{i}\right)\right)+\left(1-P^{f}-P^{r}\right)\left(\bar{W}+S\left(Q_{j}-\bar{Q}\right)\right) A_{j}-C E_{j}-C M_{i j}\right]}{\exp \left[P_{i}^{s} W_{i}+\left(1-P_{i}^{s}\right)\left(\bar{W}+S\left(Q_{i}-\bar{Q}\right)\right)-C E_{i}\right]}
$$

For the sake of simplicity, we assume a linear premium function $S\left(Q_{i}-Q_{j}\right)=a\left(Q_{i}-Q_{j}\right)$.

Migration costs, $C M_{i j}$ are composed of two parts, fixed costs $\left(C_{i}\right)$ and variable costs $\left(C_{i j}\right)$. The fixed part measures the costs of moving, independently of the destination country (homespecific costs) whereas the variable part depends both on origin and destination (like transportation costs, assimilation costs ...). The variable migration costs depend on dyadic factors such as physical distance $d_{i j}$, origin and destination countries' cultural and linguistic proximity such as the use of a common official language $\left(l_{i j}\right)$ or the existence of colonial links $\left(\operatorname{col}_{i j}\right)$ and the size

\footnotetext{
${ }^{9}$ There are two main arguments in favor of this assumption. First, agents need to form expectations about $P^{f}$ and $P^{r}$. To that aim, they need to rely on the available information. In that respect, there is so far no information available across a whole range of origin and destination countries. As a result, agents are more likely to form expectations based on average levels. Second, stay rates of students in a limited number of OECD countries have not been found to differ significantly, ranging from $14.7 \%$ to $29.5 \%$ (see in particular OECD, 2010, Page 45, Table I.8).
} 
of the migrants' network at destination $\left(M_{i j}\right)$. In line with the empirical literature on migration networks, networks at destination lead to a decrease in migration costs (see Beine et al. (2011) and McKenzie and Rapoport (2011):

$$
C M_{i j}=C_{i}+C\left(d_{i j}, l_{i j}, \operatorname{col}_{i j}, M_{i j}\right)
$$

With these assumptions, taking logs and after some manipulation, equation (3) becomes:

$$
\begin{aligned}
& \ln \left[N_{i j}\right]=\ln \left(N_{i i}\right)+(\bar{W}-a \bar{Q})\left(P_{i}^{s}-P^{f}-P^{r}\right)+W_{i}\left(P^{r}-P_{i}^{s}\right)+a Q_{i}\left(P_{i}^{s}+P^{r}-1\right)+C E_{i}-C_{i}+ \\
& \underbrace{\underbrace{P^{f} W_{j}+a\left(1-P^{f}\right) Q_{j}}_{\text {earnings }}+\underbrace{A_{j}}_{\text {attractiveness }}-\underbrace{C E_{j}}_{\text {educational costs }}}_{\text {specific destination variables }}-\underbrace{\underbrace{C\left(d_{i j}, l_{i j}, c o l_{i j}, M_{i j}\right)}_{\text {migration costs }}}_{\text {dyadic variables }}
\end{aligned}
$$

\section{DATA}

\subsection{International students versus foreign students}

To study the determinants of the choice of location of mobile students, the explained variable has to represent students who migrated for the sake of education and not for other reasons such as family migration. Moreover, the institutional migration like ERASMUS or SOCRATES programs is not suitable for this paper because the choice of location is constrained by the number of agreements a university in the host country may have abroad. Thus, some destination countries could not be chosen by students because of the absence of agreement, which could bias our analysis. Moreover, a semester or a year abroad could be compulsory in some curriculum, which does not reflect the willingness of students to migrate by themselves in a foreign country.

UNESCO, OECD and EUROSTAT (UOE) collect data on the students enrolled outside their country of birth or citizenship. Two types of data are available. First, data on foreign students where the criterion used is the citizenship of the student. This definition is not suitable for this paper because it often includes a number of students who either migrated with their parents or have been resident in the host country since birth. Second, UOE collects data on international students. International students are those who migrate solely for the purpose of education. It is exactly what we study in this paper.

To measure the number of international students settled in one country, two criteria could be used. The first one is the permanent residence criterion. If students are not permanent residents of the country, they are considered as mobile. The second criterion involves the place of prior education (Table 9, in appendix, presents the criterion used to define international students by country). Thereby, students enrolled in an OECD country who were registered in another country the year before are considered as students in mobility. Whatever the definition used 
to define the international students, data include a small group of non-resident nationals who have returned to their country of citizenship. However, this part of international students is less important than the gap between foreign students and international students. Table 10 presents both figures for international students and foreign students for the year 2007. On average, international students represent $71 \%$ of the stock of foreign students. Because this paper studies the individual migration of students for the aim of study, we focus on the number of international students in OECD countries. Data on international students is not available for all OECD countries and our analysis is limited to 13 of them : Australia, Belgium, Canada, Denmark, Germany, Ireland, the Netherlands, New Zealand, Spain, Sweden, Switzerland, the United Kingdom and the United States. Other countries either report data on foreign students and not on international students or do not give data for the period considered (from 2004 to 2007). As UOE collected data for students registered for the full academic year, it does not include students who migrate through an institutional program like ERASMUS or SOCRATES.

\subsection{Other data}

Following our theoretical framework, we relate the flows of mobile students to a set of different determinants. These can be classified into different categories.

The first one is a set of dyadic variables influencing the cost of student mobility. Migration costs are supposed to depend on distance between the two countries $\left(d_{i j}\right)$, language proximity captured by a dummy variable stating whether the two countries share a common official language $\left(l_{i j}\right)$, the existence of a colonial link $\left(\operatorname{col}_{i j}\right)$ and the size of the network at destination $\left(M_{i j}\right)$. Network is defined as the stock of migrants from the origin country living at destination. Those migrants are likely to provide assistance and information to students from their country and therefore decrease their migration costs. ${ }^{10}$

The second categorie includes a set of specific destination variables which can be grouped into three components : the expected earnings, the educational costs and the others attractiveness variables (see equation (5)).

For the expected earnings, a distinction is made in the theoretical model between the wage condition at destination $\left(w_{j}\right)$ and an expected premium which depends on the quality of education $\left(r a n k_{j}\right)$. In order to capture the wage conditions at destination, we use two alternative measures. First, following Rosenzweig (2008), we use the skill premia at destination ( $s k i l l p_{j}$ ). Those are nevertheless estimated and collected for the destination countries from Psacharopoulos and Patrinos (2002). Second, as an alternative to the skill premia, we use wage data from the OECD

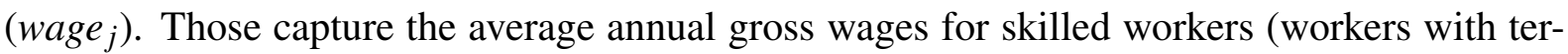
tiary education level). The reference year is 2008 or 2009 depending on the destination country.

\footnotetext{
${ }^{10}$ They can also provide information regarding job opportunities after studying. In that respect, network could also enter in terms of modeling in the benefit side of migration. Nevertheless, what matters is the net gain associated to each choice, which implies both modeling approaches yield equivalent observational implications.
} 
Note that the data is not available for Switzerland but based on auxiliary information, we use the wage level in Luxembourg as a proxy. For the quality of the higher education system, we use the 500 Shanghai ranking. More precisely, an index ratio is built with the number of national universities in the 500 shanghai ranking in the numerator and the number of students enrolled for higher education in the denominator. The number of universities in the top 500 is weighted by the size of the higher education system. Using the Shanghai ranking as a measure of quality could be open to criticism because of the criteria used to built this ranking. However, this ranking is well known from students who want to migrate and is harmonized between countries.

Concerning the educational costs, we use the average fees at destination $\left(\right.$ fees $\left._{j}\right)$. Because data on fees paid by mobile students is, to our knowledge, not available, we collect data on fees paid by natives (OECD).

Others attractiveness variables incorporate the cost of living in a country (livingcost ${ }_{j}$ ) which impacts the affordability of education in that it increases the total amount of money required to complete each year of study. The data found in Usher and Cervenan (2005) includes the costs of rent and food for an academic year. We also include the total population at destination $\left({\text { } о p_{j}}_{j}\right)$ as a proxy for the host capacity of destination countries.

Table 1 - Data presentation

\begin{tabular}{|c|c|c|c|}
\hline Variable & Definition & Source & $\begin{array}{l}\text { Available } \\
\text { Years }\end{array}$ \\
\hline$N_{i j}$ & $\begin{array}{l}\text { Mobile students } \\
\text { Number of mobile students from an origin } \\
\text { country } i \text { to the destination country } j\end{array}$ & $\begin{array}{l}\text { UNESCO } \\
\text { OECD EU- } \\
\text { ROSTAT } \\
\text { (UOE) }\end{array}$ & $\begin{array}{l}2004-2007 \\
\text { except the } \\
\text { year } 2005 \\
\text { for Canada }\end{array}$ \\
\hline$M_{i j}$ & $\begin{array}{l}\text { Migrants network } \\
\text { Total migration stock from origin country } i \\
\text { to destination country } j\end{array}$ & $\begin{array}{l}\text { Docquier } \\
\text { and Marfouk } \\
\text { database } \\
\text { (DM06) }\end{array}$ & 2000 \\
\hline$\overline{M_{i j}}$ & $\begin{array}{l}\text { Stock of migrants without upper secondary } \\
\text { education from origin country } i \text { to destina- } \\
\text { tion country } j \\
\text { Stock of migrants with a post-secondary ed- } \\
\text { ucation from origin country } i \text { to destination } \\
\text { country } j\end{array}$ & DM 06 & 2001 \\
\hline$d_{i j}$ & $\begin{array}{l}\text { Dyadic cost variables } \\
\text { Distance from origin country } i \text { to destination } \\
\text { country } j\end{array}$ & $\begin{array}{l}\text { CEPII } \\
\text { database }\end{array}$ & - \\
\hline
\end{tabular}




\begin{tabular}{|c|c|c|c|}
\hline Variable & Definition & Source & $\begin{array}{l}\text { Available } \\
\text { Years }\end{array}$ \\
\hline$l_{i j}$ & Existence of a common official language & $\begin{array}{l}\text { CEPII } \\
\text { database }\end{array}$ & - \\
\hline $\operatorname{col}_{i j}$ & Existence of a colonial link after 1945 & $\begin{array}{l}\text { CEPII } \\
\text { database }\end{array}$ & - \\
\hline \multicolumn{4}{|c|}{ Destination specific variables } \\
\hline skillp $_{j}$ & $\begin{array}{l}\text { Skill price estimated by private return to } \\
\text { schooling }\end{array}$ & $\begin{array}{l}\text { Psacharopoulos } \\
\text { and Patrinos } \\
(2002)\end{array}$ & 2002 \\
\hline pop $_{j}$ & $\begin{array}{l}\text { Population in million for the destination and } \\
\text { origin countries }\end{array}$ & FMI & 2004-2007 \\
\hline efftotd & $\begin{array}{l}\text { Number of students pursuing education in a } \\
\text { higher education institution }\end{array}$ & UNESCO & 2004-2007 \\
\hline rank500 & $\begin{array}{l}\text { Number of universities classified in the } \\
\text { Shanghai top } 500 \text { ranking }\end{array}$ & $\begin{array}{l}\text { Shanghai } \\
\text { ranking }\end{array}$ & 2004-2007 \\
\hline $\operatorname{rank}_{j}$ & $\frac{\text { rank } 500}{\text { efftotd }}$ & $\begin{array}{l}\text { UNESCO } \\
\text { and Shanghai } \\
\text { ranking }\end{array}$ & 2004-2007 \\
\hline \multirow[t]{8}{*}{ fees $_{j}$} & $\begin{array}{l}\text { Annual average tuition fees charged by } \\
\text { tertiary-type-A educational institutions for } \\
\text { full-time native students in US dollars }\end{array}$ & $\begin{array}{l}\text { OECD }(2006, \\
2007)\end{array}$ & $\begin{array}{l}\text { Academic } \\
\text { year 2003- } \\
2004\end{array}$ \\
\hline & & & except for \\
\hline & & & Ireland, \\
\hline & & & Nether- \\
\hline & & & $\begin{array}{l}\text { lands } \\
\text { (academic }\end{array}$ \\
\hline & & & year 2004- \\
\hline & & & 2005). No \\
\hline & & & $\begin{array}{l}\text { data for } \\
\text { Germany. }\end{array}$ \\
\hline
\end{tabular}

wage $_{j} \quad$ Gross annual wage for workers with tertiary

OECD: educa- 2008 or education level 


\begin{tabular}{llll} 
Variable & Definition & \multicolumn{1}{c}{ Table 1 - suite } & Source \\
\hline livingcost $_{j}$ & $\begin{array}{l}\text { The cost of living (in US dollars 2003) in } \\
\text { a country materially impacts the affordabil- } \\
\text { ity of education in that it increases the total } \\
\text { amount of money required to complete each } \\
\text { year of study. Living costs include the cost } \\
\text { of rent and food for an academic year. }\end{array}$ & $\begin{array}{l}\text { and } \\
\text { Years }\end{array}$ \\
\hline
\end{tabular}

\section{MEASURING DETERMINANTS OF STUDENT'S MIGRATION}

\subsection{Econometric approach}

\subsubsection{Implied specifications}

Starting from equation (5), the benchmark estimable relationship between international student migration flows and their determinants is the following:

$$
\ln \left(N_{i j}\right)=\alpha+\alpha_{i}+\alpha_{j}+\beta_{1} * \ln \left(d_{i j}\right)+\beta_{2} * \ln \left(\operatorname{col}_{i j}\right)+\beta_{3} * \ln \left(l_{i j}\right)+\beta_{4} * \ln \left(M_{i j}\right)+v_{i j}+\varepsilon_{i j}
$$

where $v_{i j}$ captures the unobserved bilateral factors and $\varepsilon_{i j}$ is an error term and $\alpha=(\bar{W}-$ $a \bar{Q})\left(P^{f}-P^{r}\right)$. In this specification, unobserved factors that are origin and destination specific are captured by $\alpha_{i}$ and $\alpha_{j}$. More precisely, we have :

$$
\alpha_{i}=C E_{i}-C_{i}+W_{i}\left(P^{r}-P_{i}^{s}\right)+a Q_{i}\left(P_{i}^{s}+P^{r}-1\right)+P_{i}^{s}(\bar{W}-a \bar{Q})+\ln \left(N_{i i}\right)
$$

Similarly, we have:

$$
\alpha_{j}=P^{f} W_{j}+a\left(1-P^{f}\right) Q_{j}+A_{j}-C E_{j}
$$

The aim of this particular specification is to maximize the fit of the model to the data and to focus on the role of the dyadic factors such as flying distance $\left(d_{i j}\right)$, the existence of a colonial link $\left(\operatorname{col}_{i j}\right)$, the use of a common official language $\left(l_{i j}\right)$ and the network effect $\left(M_{i j}\right)$.

In contrast, specification (6) does not allow to capture the role of factors that are destination specific. In the context of international competition between countries for young talents, such an analysis is very important to shed some light of the determinants of the attractiveness of each country as a supplier of higher education and therefore to issue policy recommendations to increase this attractiveness. To this aim, we replace $\alpha_{j}$ by destination specific observable variables involved in its definition. Following equation (8), we consider 5 variables: skill prices (in 
the destination country) $\left(s k i l l p_{j}\right)$ or wages for workers with a tertiary education level ((wage $\left.e_{j}\right)$ as an incentive for students to work at destination after they have completed their education (a proxy of $W_{j}$ ), the measure of prestige and quality of the universities ( $\operatorname{rank}_{j}$ as a proxy of $Q_{j}$ ), the average fees $\left(\right.$ fees $\left._{j}\right)$ and the average living cost (livingcost $\left.t_{j}\right)$ and population $\left(\right.$ Pop $\left._{j}\right)$ as a proxy for the host capacity of the country.

The implied specification becomes :

$$
\begin{array}{r}
\ln \left(N_{i j}\right)=\alpha_{i}+\beta_{1} * \ln \left(d_{i j}\right)+\beta_{2} * \ln \left(\operatorname{col}_{i j}\right)+\beta_{3} \ln *\left(l_{i j}\right)+\beta_{4} \ln \left(M_{i j}\right)+\beta_{5} * \ln \left(w_{j}\right)+ \\
\beta_{6} * \ln \left(\text { Rank }_{j}\right)+\beta_{7} * \ln \left(\text { Pop }_{j}\right)+\beta_{8} * \ln \left(\text { living }_{\text {inost }}\right)+\beta_{9} * \ln \left(\text { fees }_{j}\right)+v_{i j}+\varepsilon_{i j}
\end{array}
$$

\subsection{Results}

\subsubsection{Benchmark regressions at the bilateral level}

We first start with the regressions allowing to capture the impact of bilateral factors (equation (6)). In a first step, we leave out a discussion about the role of the unobservable bilateral factors $\left(v_{i j}\right)$ and the impact of their omission. We address this issue specifically later on. In specification 6 , the role of country specific variables are captured by destination and origin country fixed effects. This specification yields in general a better fit and is suited to uncover in a more precise way the role of factors that are specific to each migration corridor. Among those factors, we include the role of linguistic links, of the colonial links, of the migrants' network at destination and of the euclidean distance between the origin and the destination. We have actually 4 waves of data: 2004, 2005, 2006 and 2007. Nevertheless, we do not pool the data. The reason is two-fold. First, pooling the data and accounting for unobserved heterogeneity would lead to the inclusion of country pairs specific effect. In turn, this would absorb the role of bilateral factors that are constant over time like colonial links, linguistic links and distance. Second, for the network, we have only data for 2000 and we use that information in each regression period. Pooling the data therefore would introduce some redundant information and like for the other bilateral factors, their impact would be absorbed by the bilateral fixed effect.

One of the econometric issue at stake in this analysis is related to high proportion of zeros. Depending on the period, the proportion of zero values in the stock of students at the dyadic level varies between $18 \%$ and $30 \% .{ }^{11}$ Like in other analyses involving international flows such as trade and FDI, the high prevalence rate of zeros creates specific issues that prevent the use of OLS estimates. The first issue is that taking the log of the flows values drops the observations with zero students. This in turn induces a selection bias since the country pairs with zero values are likely to have a population distribution that differs from the underlying one of the pairs with positive flows. Using the log of the observed flows plus one instead of the log or using some Tobit estimator prevents such a bias. Nevertheless, as shown by Santos Silva and

\footnotetext{
${ }^{11}$ Starting from the full sample involving only $N_{i j}$, the proportion of zeros is $17.9 \%, 27.09 \%, 24.42 \%$ and $29.97 \%$ respectively for the years 2004, 2005, 2006 and 2007.
} 
Tenreyro (2006), in presence of heteroskedasticity, the presence of zeros creates some correlation between the covariates and the error term, leading to inconsistency of OLS estimates. The solution they propose is to use the Poisson maximum likelihood estimator which minimizes the bias in Monte Carlo simulations under a set of alternative stochastic processes. Therefore, we rely on the Poisson ML estimates to estimate models (6) and (9). ${ }^{12}$ We make sure the standard errors are adjusted using robust estimates. Table 2 reports the estimation results for the benchmark regressions for the 4 years.

Table 2 - Determinants of student's migration Bilateral regressions

\begin{tabular}{|c|c|c|c|c|c|c|c|c|}
\hline Years & (2004) & (2005) & (2006) & (2007) & (2004) & (2005) & (2006) & (2007) \\
\hline \multirow[t]{2}{*}{ Variables } & \multicolumn{4}{|c|}{ Total network } & \multicolumn{4}{|c|}{ Skilled network } \\
\hline & (2) & (3) & (4) & (5) & (6) & (7) & (8) & (9) \\
\hline Distance & $\begin{array}{c}-0.672 * * * \\
(0.077)\end{array}$ & $\begin{array}{c}-0.705 * * * \\
(0.067)\end{array}$ & $\begin{array}{c}-0.669 * * * \\
(0.067)\end{array}$ & $\begin{array}{c}-0.691 * * * \\
(0.066)\end{array}$ & $\begin{array}{c}-0.587 * * * \\
(0.058)\end{array}$ & $\begin{array}{c}-0.606 * * * \\
(0.072)\end{array}$ & $\begin{array}{c}-0.591 * * * \\
(0.061)\end{array}$ & $\begin{array}{c}-0.609 * * * \\
(0.060)\end{array}$ \\
\hline \multirow[t]{2}{*}{ Colony } & 0.028 & 0.021 & 0.112 & 0.104 & -0.091 & -0.103 & -0.004 & -0.015 \\
\hline & $(0.219)$ & $(0.225)$ & $(0.193)$ & $(0.187)$ & $(0.216)$ & $(0.219)$ & $(0.187)$ & $(0.178)$ \\
\hline \multirow[t]{2}{*}{ Language } & $1.131 * * *$ & $0.909 * * *$ & $1.044 * * *$ & $1.130 * * *$ & $1.007 * * *$ & $0.784 * * *$ & $0.924 * * *$ & $1.003 * * *$ \\
\hline & $(0.203)$ & $(0.178)$ & $(0.178)$ & $(0.180)$ & $(0.194)$ & $(0.166)$ & $(0.168)$ & $(0.168)$ \\
\hline \multirow[t]{2}{*}{ Network } & $0.272 * * *$ & $0.281 * * *$ & $0.275 * * *$ & $0.282 * * *$ & $0.406 * * *$ & $0.418 * * *$ & $0.405 * * *$ & $0.415 * * *$ \\
\hline & $(0.049)$ & $(0.053)$ & $(0.045)$ & $(0.042)$ & $(0.049)$ & $(0.051)$ & $(0.045)$ & $(0.043)$ \\
\hline \# obs & 2442 & 2256 & 2432 & 2444 & 2442 & 2252 & 2432 & 2444 \\
\hline \# orig c & 203 & 203 & 203 & 203 & 203 & 203 & 203 & 203 \\
\hline$\#$ dest c & 13 & 12 & 13 & 13 & 13 & 12 & 13 & 13 \\
\hline Pseudo $R^{2}$ & 0.927 & 0.933 & 0.934 & 0.934 & 0.932 & 0.938 & 0.939 & 0.939 \\
\hline Orig FE & yes & yes & yes & yes & yes & yes & yes & yes \\
\hline Dest FE & yes & yes & yes & yes & yes & yes & yes & yes \\
\hline
\end{tabular}

Notes: Years refer to the estimation period. Poisson ML estimates. Robust standard errors between parentheses. $*, * *$ and $* * *$ denote significance at the 10,5 and $1 \%$ significance levels.

For all regressions, network refers to the stock of migrants observed in 2000.

Columns (2)-(5): network equals stock of all migrants.

Columns (6)-(9): network equals stock of migrants with tertiary education.

From column (2) to (5), we use the total stock of migrants $\left(M_{i j}\right)$ observed in 2000 as a measure of the network while the last four columns report the results with the stock of migrants with tertiary education level only $\left(\overline{M_{i j}}\right)$. Table 2 shows that there is a strong convergence in the results between the four years under investigation, both from qualitative and quantitative point of view. Distance turns out to be a strong determinant of the number of students going

\footnotetext{
${ }^{12}$ For the sake of information, Appendix 2 presents the results obtained from alternative regression techniques. We use 4 alternative methods: OLS on the dependent variable (log of number students) which drops out the zero observations, OLS on the log of (1+number of students), which includes the zero observations, a two-step Heckman procedure and finally Tobit estimation method. Two-step Heckman method assumes a selection process for the pairs with a positive number of students. Note that following Santos Silva and Tenreyro (2006), all those four methods yield biased estimates in the presence of zero observations.
} 
abroad. Distance usually picks up the impact of transportation costs and psychological costs of being abroad. Likewise, language proximity between the origin and the destination impacts positively the flows of students studying abroad. This is consistent with the hypothesis of skill transferability (Chiswick (1978)) where linguistic abilities seem important for (future) skilled workers. Our estimates support also a strong network effect which has not been documented in the existing literature so far. The elasticity of the total network is around 0.28. Interestingly, this elasticity, around 0.41 , is stronger for the skilled diaspora (column (6) to (9)), favoring the view that students in higher education benefit more from support of skilled migrants at destination. Additional unreported results confirm that the education level of the diaspora induces a different impact in network effect for students. For instance, for 2007, the elasticity associated to the unskilled diaspora (migrants with primary education level, $\left(M_{i j}\right)$ ) is equal to 0.156 , showing that the variation of the network elasticity is more or less linear with respect to education of the network. Furthermore, the effects of network tends to absorb the traditional role of colonial relationships. This suggests that students tend to choose the former colonizer as their preferred destination not because of past colonial relationships but because they can rely on people from their origin country.

The network effect could be nevertheless the result of the fact that model (6) includes $v_{i j}$. If the migration network is correlated with the non observable factors of international students, this creates a correlation between the network and the composite error term $v_{i j}+\varepsilon_{i j}$, biasing the ML estimates. In the literature dealing with international migration, this is called the problem of correlated effects (Manski (1993)). Nevertheless, this might be relevant in our context, too. For instance, it could be the case if destination countries that conduct some privileged migration policies with respect to some origin countries (thereby favoring a high value for $M_{i j}$ ) are also keen to favor the arrival of students from those countries. Put differently, if the bilateral student migration policies tend to follow the general pattern of migration policies concerning economic migrants or family reunification programs, then the estimates of model (6) can be biased.

The solution to the correlated effect problem lies in the use of instrumental variables estimates. Instrumenting the network with a variable correlated with the network in 2000 but uncorrelated with the subsequent flows of students allows to get rid of that potential problem. We follow that strategy to assess whether our estimate of the network effect is not affected by the correlated effect problem. Given the presence of zeroes, one need nevertheless to combine Poisson and instrumental variable estimation. This has been suggested by Tenreyro (2007) in the context of the GMM framework. The idea is to start from the underlying orthogonality condition associated to the Poisson estimator. Aggregating all explanatory variables $\alpha_{i}, \alpha_{j}, d_{i j}, \operatorname{col}_{i j}, l_{i j}$ and $M_{i j}$ into the $x_{i j}$ vector, the Poisson estimator $\gamma$ solves the following moment condition:

$$
E\left(\left[N_{i j}-\exp \left(x_{i j} \gamma\right)\right] x_{i j}=0\right)
$$

In order to instrument $x_{i j}$, one can use as an alternative the following GMM estimator denoted by $\psi$ :

$$
E\left(\left[N_{i j}-\exp \left(x_{i j} \psi\right)\right] z_{i j}=0\right)
$$


in which $z_{i j}$ represent the vector of exogenous variables and of the instruments, i.e. variables that are supposed to be correlated with $M_{i j}$ but uncorrelated with $N_{i j}$. For the choice of the instrument, we follow Beine et al. (2011) and use the existence of guest worker programs in the 60's and 70's as an instrument for $M_{i j}$. Guest worker programs were implemented after the second world war in a lot of industrialized countries to attract economic migrants for the explicit purposes of working in specific industries like coal mines or steel factories. They were mostly dropped at the beginning of the 70's. Those bilateral agreements led to the building of important diasporas in the destination countries and are good predictors of the value of the migrant networks in 2000. In contrast, those bilateral agreements did not change the subsequent bilateral migration policies in general, and certainly not the one concerning students.

The results of that estimation for the year 2007 are reported in Table 3. Once again we consider two measures of the migrants network. In column (2) we report the results with the total network while in column (3) we use only the skilled network. The results are in line with those of Table 2 and suggest that the network effect is not an artefact associated to the correlated effect problem. In particular, we find a positive elasticity of the students flows with respect to the stock of migrants. We also find that the elasticity is higher for the skilled network, although the difference is less important.

Table 3 - Determinants of student's migration GMM estimates instrumenting network

\begin{tabular}{|l|c|c|}
\hline Variables & $\begin{array}{c}\text { Total network } \\
(2)\end{array}$ & $\begin{array}{c}\text { Skilled network } \\
(3)\end{array}$ \\
\hline Distance & $-0.361 * * *$ & $-0.458^{* * *}$ \\
& $(0.045)$ & $(0.040)$ \\
Colony & -0.009 & $0.111^{* * *}$ \\
& $(0.189)$ & $(0.143)$ \\
Language & $0.503 * * *$ & $0.288^{* * *}$ \\
& $(0.136)$ & $(0.114)$ \\
Network & $0.412 * * *$ & $0.482 * * *$ \\
& $(0.036)$ & $(0.033)$ \\
\hline \# obs & 2301 & 2301 \\
Origin FE & yes & yes \\
Destin FE & yes & yes \\
\hline
\end{tabular}

Notes: Estimation period : 2007

Column (2): network equals stock of all migrants

Column (3): network equals stock of migrants with tertiary education.

Robust standard errors in GMM estimates

Instrument : presence of guest worker programs 


\subsubsection{The role of destination specific variables}

The previous analysis does not allow to capture factors that are specific to destination countries. Among those factors, variables that are related to attractiveness such as the prestige of the universities at destination can be of tremendous importance. Also, since cost of living and education fees vary a lot across destinations, this should play a significant role in the decision made by students about moving abroad to complete their education.

Therefore we estimate model (9) and focus on the role of destination specific variables. Given that the inclusion of observable destination specific factors leaves out unobserved factors that were previously captured by the destination fixed effects, this specification is sub-optimal from a pure statistical point of view. We should expect that the goodness of fit is lower and that the role of bilateral variables such as the network is not so well captured in this estimation. In contrast, the model allows to recover the impact of destination specific factors. We consider five destination specific factors: population size which is a proxy of the host capacity for students in general; fees and living costs that are the most important cost components for students; ranking of university as a variable capturing quality of the universities of that country; skill prices prevailing in destination countries.

The estimation of the impact of destination specific factors yields interesting insights. Ranking, as a proxy of the average quality of the universities, is clearly significant as a powerful magnet for foreign students. The positive impact is robust across all specifications included in Table 4 . It is also robust to the choice of the exact ranking (Top 100 vs Top 500) we refer to. The results support the idea that housing costs play an important role in the migration and enrollment of foreign students. In contrast to fees which embed several possible effects, living expenses are clearly an important cost component of foreign education. ${ }^{13}$

Regarding the incentives to study for the sake of working afterwards in the country, we do not find any significant role for skill prices at destination (see results in column (2)). This might be due to the low variation of skill premia estimates across destination countries. Also, those skill premia are not directly observed but rather estimated, which implies that they are plagued with measurement errors. As an alternative, we use the wage level at destination, as proxied by the average wage of workers with tertiary education level. Note that, due to missing data, the number of observations is reduced, which induces a sample effect with respect to the other specifications. Nevertheless, we find support for a positive impact of wage on the destination choice. This is line with some support in favor of the migration model of Rosenzweig (2008).

\footnotetext{
${ }^{13}$ The inclusion of living costs is only possible as destination specific components in model (9). The use of the differential in living costs between the origin and destination countries would require data on living cost indexes in developing countries, which is not available worldwide. Furthermore, when available, the measures of living costs for a subset of origin countries are not comparable across countries. In contrast, the living costs in destination countries are highly comparable, which is important in a multi-destination framework like ours.
} 
Table 4 - Determinants of student's migration Regressions with destination specific factors

\begin{tabular}{|c|c|c|c|c|c|c|}
\hline Variables & (1) & (2) & (3) & (4) & (5) & (6) \\
\hline Constant & $\begin{array}{c}43.078 * * * \\
(3.499)\end{array}$ & $\begin{array}{c}41.714 * * * \\
(3.893)\end{array}$ & $\begin{array}{c}41.554 * * * \\
(3.784)\end{array}$ & $\begin{array}{c}43.137 * * * \\
(4.354)\end{array}$ & $\begin{array}{c}38.821 * * * \\
(3.911)\end{array}$ & $\begin{array}{c}39.821 * * * \\
(3.643)\end{array}$ \\
\hline Distance & $\begin{array}{c}-0.372 * * * \\
(0.063)\end{array}$ & $\begin{array}{c}-0.474 * * * \\
(0.076)\end{array}$ & $\begin{array}{c}-0.426 * * * \\
(0.062)\end{array}$ & $\begin{array}{c}-0.361 * * * \\
(0.059)\end{array}$ & $\begin{array}{c}-0.552 * * * \\
(0.066)\end{array}$ & $\begin{array}{c}-0.515^{* * * *} \\
(0.066)\end{array}$ \\
\hline Colony & $\begin{array}{c}-0.691 * * * \\
(0.201)\end{array}$ & $\begin{array}{c}-0.348 \\
(0.212)\end{array}$ & $\begin{array}{c}-0.477 * * * \\
(0.179)\end{array}$ & $\begin{array}{c}-0.477 * * * \\
(0.187)\end{array}$ & $\begin{array}{c}-0.178 \\
(0.166)\end{array}$ & $\begin{array}{c}-0.327 * \\
(0.179)\end{array}$ \\
\hline Language & $\begin{array}{c}1.090 * * * \\
(0.189)\end{array}$ & $\begin{array}{c}1.070 * * * \\
(0.207)\end{array}$ & $\begin{array}{c}1.045^{* * *} * \\
(0.198)\end{array}$ & $\begin{array}{c}1.008 * * * \\
(0.174)\end{array}$ & $\begin{array}{c}1.540 * * * \\
(0.143)\end{array}$ & $\begin{array}{c}1.531 * * * \\
(0.140)\end{array}$ \\
\hline Network & $\begin{array}{c}0.465^{* * * *} \\
(0.048)\end{array}$ & $\begin{array}{c}0.388 * * * \\
(0.053)\end{array}$ & $\begin{array}{c}0.421 * * * \\
(0.048)\end{array}$ & $\begin{array}{c}0.462 * * * \\
(0.051)\end{array}$ & $\begin{array}{c}0.353 * * * \\
(0.030)\end{array}$ & $\begin{array}{c}0.381 * * * \\
(0.029)\end{array}$ \\
\hline Population & $\begin{array}{c}0.493 * * * \\
(0.073)\end{array}$ & $\begin{array}{c}0.527 * * * \\
(0.071)\end{array}$ & $\begin{array}{c}0.479 * * * \\
(0.069)\end{array}$ & $\begin{array}{c}0.498 * * * \\
(0.071)\end{array}$ & $\begin{array}{c}-0.270 * * * \\
(0.099)\end{array}$ & $\begin{array}{c}-0.465 * * * \\
(0.146)\end{array}$ \\
\hline Ranking & $\begin{array}{c}0.262 * * * \\
(0.093)\end{array}$ & $\begin{array}{c}1.199 * * * \\
(0.210)\end{array}$ & $\begin{array}{c}1.294 * * * \\
(0.177)\end{array}$ & $\begin{array}{c}1.306 * * * \\
(0.165)\end{array}$ & $\begin{array}{c}0.387^{*} \\
(0.213)\end{array}$ & $\begin{array}{c}-0.157 \\
(0.306)\end{array}$ \\
\hline Living cost & $\begin{array}{c}-6.452 * * * \\
(0.714)\end{array}$ & $\begin{array}{c}-5.010 * * * \\
(0.606)\end{array}$ & $\begin{array}{c}-4.914 * * * \\
(0.548)\end{array}$ & $\begin{array}{c}-5.211 * * * \\
(0.698)\end{array}$ & $\begin{array}{c}-10.876^{* * *} * \\
(0.791)\end{array}$ & $\begin{array}{c}-12.317 * * * \\
(1.297)\end{array}$ \\
\hline Fees & $\begin{array}{l}0.072 * \\
(0.039)\end{array}$ & $\begin{array}{c}0.148 * * * \\
(0.041)\end{array}$ & $\begin{array}{c}0.130 * * * \\
(0.034)\end{array}$ & $\begin{array}{l}- \\
-\end{array}$ & $\begin{array}{c}0.003 \\
(0.028)\end{array}$ & $\begin{array}{c}-0.056 \\
(0.044)\end{array}$ \\
\hline Fees*Quality & $\begin{array}{c}17.39 * * * \\
(4.84)\end{array}$ & $\begin{array}{l}- \\
-\end{array}$ & $\begin{array}{l}- \\
-\end{array}$ & - & $\begin{array}{l}- \\
-\end{array}$ & $\begin{array}{c}15.765 * * * \\
(6.65)\end{array}$ \\
\hline Skill prices & - & $\begin{array}{l}-0.051 \\
(0.048)\end{array}$ & - & - & $\begin{array}{l}- \\
-\end{array}$ & $\begin{array}{l}- \\
-\end{array}$ \\
\hline Wages & - & $\begin{array}{l}- \\
-\end{array}$ & $\begin{array}{l}- \\
-\end{array}$ & $\begin{array}{l}- \\
-\end{array}$ & $\begin{array}{c}5.498 * * * \\
(0.813)\end{array}$ & $\begin{array}{c}5.537 * * * * \\
(0.786))\end{array}$ \\
\hline \# observations & 2068 & 2068 & 2068 & 2256 & 1880 & 1880 \\
\hline Pseudo $R^{2}$ & 0.930 & 0.928 & 0.927 & 0.912 & 0.933 & 0.935 \\
\hline Origin FE & yes & yes & yes & yes & yes & yes \\
\hline Destination FE & no & no & no & no & no & no \\
\hline
\end{tabular}

Notes: Estimation period : 2007. Poisson ML estimates.

Robust standard errors between parentheses.

Network refers to the stock of migrants observed in 2000.

The estimation results reflect some unexpected sign for the effect of enrollment fees. The direct estimation of model (9) (columns (2) and (3)) yield positive impact for the fees. This positive impact is robust to the inclusion or not of the skill prices as well as various measures of quality for the university. Clearly, the impact of fees goes well beyond a pure cost component. We therefore need to explore some alternative interpretations of the explicit channel by which fees 
impact the attraction of foreign students.

First, fees can also exert a signal for quality. High fees might reflect high quality, which attracts further students. To shed light on the possibility of such a signaling channel for fees, we add to the controls in model (9) an interaction term between fees and quality of universities in the country (measured by the relative presence in the Top 500 ranking). Column (1) of Table 4 displays the results. The result for the direct impact of fees remains similar, with a positive impact, albeit less significant than in the benchmark estimations (columns (2) and (3)). The interaction term between fees and quality displays a highly significant impact, which shows some support for a signaling effect of quality for fees. For countries with a high perceived quality of the tertiary education system, higher fees tend to attract further students. This result is also confirmed with wages included as potential determinants.

A second complementary interpretation of the direct positive impact of fees might be related to reverse causality. A positive impact might indeed be driven by reverse causality in the sense that countries like the United States whose universities turn out to be attractive for foreign students can afford to charge higher fees. In some universities, acceptation of foreign students might only occur if those students pay significant fees. Otherwise, there is little incentive to accept students from abroad. In universities which benefit from a good reputation of high quality and turn out to be quite attractive on a sustained basis, the university authorities can afford to set fees to high levels. This is especially true if those universities have the possibility of setting fees freely, which is more the case if they are private. In turn, grants and financial aids can be obtained by students more easily if they get admitted in universities enjoying high reputation. To test for such an interpretation, we need to instrument the fees to get rid of the possible bias triggered by the feedback effect exerted by the number of foreign students.

To address the issue of potential reverse causality from number of students to fees, we reestimate model (9) combining IV and Poisson estimators. We employ the GMM estimator (equation (11)) and use the share of the private sector in the total expenditures in the higher education system as an instrument for the fees. This ratio is clearly positively correlated with the average amount of fees. In contrast, we do not see any a priori relationship with the total number of incoming students. ${ }^{14}$ The results are reported in Table 5. We estimate model (9) for both education levels of network. In both cases, we find that fees become insignificant in explaining the magnitude of foreign students. It is worth pointing out that this is due to a large drop in the value of the coefficient and not only to a blow-up of the standard errors associated to the instrumentation process.

The insignificance of fees along with the strong impact of the living costs might be rationalized by the fact that foreign students often benefit from grants. For instance, in the US, foreign students often benefit from stipends or fellowships paying for registration fees, which they

\footnotetext{
${ }^{14}$ Furthermore, statistically speaking, this variable has only one dimension (destination specific) while the dependent variable $N_{i j}$ is dyadic. This should lead to a low correlation.
} 
receive from their government or some other organizations (e.g., the Ford Foundation), from their employer back home, or even from the universities themselves. ${ }^{15}$ Housing costs may matter possibly because the financial support does not always cover living expenses. The use of international grants could potentially be interesting in the econometric analysis to test for the validity of this conjecture. Unfortunately, data on international grants are difficult to find in a comparable form across destination countries.

Table 5 - Determinants of student's migration Accounting for reverse causality in fees

\begin{tabular}{|l|c|c|}
\hline Variables & Total network & Skilled network \\
& $(2)$ & $(3)$ \\
\hline Distance & 0.002 & $-0.232^{* * *}$ \\
& $(0.129)$ & $(0.052)$ \\
Colony & -0.688 & -0.277 \\
& $(0.434)$ & $(0.203)$ \\
Language & $0.706 *$ & 0.119 \\
& $(0.366)$ & $(0.176)$ \\
Network & $0.589 * * *$ & $0.557 * * *$ \\
& $(0.056)$ & $(0.045)$ \\
\hline Population & $0.333^{* * *}$ & $0.241^{* * *}$ \\
& $(0.103)$ & $(0.078)$ \\
Ranking & $1.624 * * *$ & $1.246 * * *$ \\
& $(0.217)$ & $(0.169)$ \\
Living cost & $-8.864 * * *$ & $-7.937 * *$ \\
& $(1.457)$ & $(1.219)$ \\
Fees & 0.032 & 0.047 \\
& $(0.075)$ & $(0.029)$ \\
\hline \# obs & 1770 & 1770 \\
Origin FE & yes & yes \\
Destination FE & no & no \\
\hline
\end{tabular}

Notes: Estimation period : 2007.

Column (2): network equals stock of all migrants.

Column (3): network equals stock of migrants with tertiary education.

Robust standard errors in GMM estimates.

Instrument : share of private sector in education expenditures.

\footnotetext{
${ }^{15}$ The Open Doors Report of the Institute of International Education (IEE (2010)) shows that the international students in the US must rely on their own funds to pay for their education - 63,5\% of their primary source of funds come from personal and family sources and 36,5\% from financial aid like grants and scholarships or fellowships. The amount of financial aid from U.S. college or universities stands at $24 \%$ of the total primary source of financing. These figures should not hide a large heterogeneity among foreign students in the US : The share of financial aid drops to $16 \%$ for undergraduates and rises to $49.4 \%$ for graduates.
} 


\subsubsection{Alternative regression methods}

Our econometric estimations rely on Poisson estimates. As argued before, the choice of this approach is motivated by the particular pattern of student flow data, including the significant proportion of zero values for those flows. Other estimation methods have been used in the migration and trade literature. In Appendix 2, we present the results obtained by four of the most popular methods used by researchers.

It should be emphasized that depending on the statistical context, alternative methods might exhibit some problems. Simple OLS method applied to the log of flows induce a selection bias and some correlation between the covariates and the error term in the presence of heteroskesaticity (Santos Silva and Tenreyro (2006)). The use of the log of 1 plus the observed flow gets rid of the selection bias but not of the the second issue. Heckman two-step regressions take explicitly the selection bias into account but are also less suited to account for the correlation with the error term; Tobit regressions also deal with zero values but assumed a truncation process. If the recorded zero values are true zeroes and do not result from some truncation process, then the estimates are also likely to suffer from estimation bias. To sum it up, our benchmark regression method, namely ML Poisson, assumes that the observed zeroes are true, does not suffer from a selection bias due to the zeroes and takes care of some correlation between covariates and the error term in presence of heteroskedastic errors. The possible diverging results between the four alternative methods and the ML Poisson partly reflect the issues mentioned here above.

Table 11 in Appendix 2 gives the results for the bilateral determinants. All in all, the results are quite consistent with the Poisson estimates. Networks, distance and linguistic links produce similar effects. Interestingly, in all regression methods, skilled networks display a higher elasticity than total network. Table 12 also gives the results for destination specific results. There is some degree of divergence with respect to Poisson regression results. For instance, ranking does not come out with the intuitive positive sign, which casts some doubt on the consistency of these estimates. Also, when combined with our measures of skilled wages, population does not display the expected positive impact. Note however that measures of wages for skilled workers are not available for all destination countries, which significantly reduces the number of country pairs. In contrast, we have consistent results regarding the influence of living costs and fees. In particular, tuition fees do not display the negative impact that would be associated to the natural interpretation of fees as a component of education cost. In that regard, those results support the ones obtained for fees with Poisson regressions. In all regressions, living costs appear to be significant cost factors for students, which is fully in line with benchmark regressions.

\subsubsection{Cost Subsidy Equivalent Measures}

Networks and quality of universities have been found to be statistically significant determinants of student migration. For policy purposes it is also interesting to get an idea of the order of magnitude of the effects of those variables. One way of quantifying (in monetary terms) these effects is to apply a methodology similar to the tariff-equivalent measures used in international 
trade literature to quantify the impact of non-tariff barriers. This tariff-equivalent is defined as the tariff that would produce the same effect, usually on the quantity of imports, as the non-tariff barrier (Anderson and van Wincoop (2004)).

In the same perspective, our objective is to measure here in monetary terms the effects of network and ranking on the number of international students attracted in the destination. To that aim, we compute living costs subsidy-equivalent measures. Our econometric results confirm that network and the quality of the higher education system have a positive impact on the attractiveness of a destination country. This effect is similar to the the one obtained by reducing the living costs through a subsidy. This living costs subsidy-equivalent measure is therefore defined as the subsidy rate needed to achieve the living costs level needed to compensate the absence of any network effect given the observed stock of migrants. ${ }^{16}$ We do that for the network including all migrants ${ }^{17}$ (or alternatively only migrants with tertiary education ${ }^{18}$ ) from an origin country. We compute the same living costs subsidy-equivalent measure to compensate for the loss of one university of the destination country in the Shanghai top 500 ranking ${ }^{19}$.

Table 6 - Living cost subsidy-equivalent of network and ranking

\begin{tabular}{|l|c|c|c|}
\hline Destination & Total network $^{(a)}$ & Skilled network $^{(b)}$ & Ranking $^{(c)}$ \\
\hline Australia & $48.62 \%$ & $34.90 \%$ & $1.04 \%$ \\
Belgium & $50.52 \%$ & $27.44 \%$ & $2.42 \%$ \\
Canada & $48.44 \%$ & $40.02 \%$ & - \\
Denmark & $42.09 \%$ & $21.23 \%$ & $4.01 \%$ \\
Germany & $48.43 \%$ & $39.68 \%$ & $0.44 \%$ \\
Ireland & $40.04 \%$ & $32.55 \%$ & $5.13 \%$ \\
Netherlands & $52.20 \%$ & $28.64 \%$ & $1.46 \%$ \\
New Zealand & $44.30 \%$ & $26.02 \%$ & $3.29 \%$ \\
Spain & $48.41 \%$ & $34.85 \%$ & $1.91 \%$ \\
Sweden & $43.36 \%$ & $37.61 \%$ & $1.58 \%$ \\
Switzerland & $48.47 \%$ & $28.78 \%$ & $2.13 \%$ \\
United Kingdom & $49.41 \%$ & $37.50 \%$ & $0.43 \%$ \\
United States & $49.63 \%$ & $45.59 \%$ & $0.11 \%$ \\
\hline
\end{tabular}

(a) Aggregate subsidy rate needed to attain the living costs level that would offset the absence of network effect associated to all migrants.

(b) Aggregate subsidy rate needed to attain the living costs level that would offset the absence of network effect associated to skilled migrants.

(c) Subsidy rate needed to attain the living costs level that would offset the loss of one university in the in the top 500 Shanghai ranking.

Since migrants network is a dyadic variable, we compute for each country pair and for both

\footnotetext{
${ }^{16}$ This subsidy rate measures the decline in relative terms that would be required to have the same number of international students in a country in the absence of network effect or one less university in the Shanghai ranking.

${ }^{17}$ Column 2 of table 6.

${ }^{18}$ Column 3 of table 6 .

${ }^{19}$ Column 4 of table 6 .
} 
types of network the living costs subsidy-equivalent. Then, starting from the subsidy rate to be applied for each origin country, we can calculate the aggregate subsidy for each destination by summing up the bilateral measures and weighting by the numbers of international students. This aggregate subsidy-equivalent measure shows the importance of network effect in the attractiveness of all these countries. It amounts to a living cost subsidy ranging from $40 \%$ in Ireland to $52.2 \%$ in the Netherlands, when we take into account the total stock of migrants. It also applies to the skilled network: we obtain subsidy rates between $21.2 \%$ in Denmark to $45.6 \%$ in the USA. This subsidy rate is lower than the rate obtained for total immigration but we should bear in mind that skilled immigrants represent only $17 \%$ of total immigration in Denmark and up to $58 \%$ in Canada. Thus, in relative terms, the effect is larger for skilled network.

While the coefficient of university ranking is positive and significant, the computation of the living costs subsidy-equivalent yields a moderate effect: one less University in the Shanghai top 500 is offset by a subsidy rate of $0.1 \%$ for the USA and $5.1 \%$ for Ireland. This limited effect of higher education quality was also established in Perkins and Neumayer (2012).

\section{CONCLUSION AND DISCUSSION}

In this paper, we have analyzed the determinants of international student mobility. Unlike the previous literature, we use a multi-origin multi-destination framework to identify the main factors at stake. Relying on a small theoretical model of human capital investment, we focus on two types of factors: those affecting the migration costs such as distance and migrants' network at destination and those affecting the attractiveness of the destination such as education costs, the quality of universities. We estimate the importance of those factors using data covering more than 180 origin countries and 13 destination countries. Our data cover more than $75 \%$ of the total international student migration flows. In the estimation, we control for the high prevalence of zero values for the bilateral flows as well as the potential econometric problems affecting the quality of our estimates. Those problems are the correlated effects between network and the dyadic unobserved determinants of flows as well the reverse causality running from education fees to student flows at equilibrium. This calls for the use of econometric techniques combining Poisson estimates and instrumental variables.

The main findings of our estimations are the following ones. As for other migration flows (like employment reasons), when looking for determinants of international mobility of students, the factors measuring the costs of migration are statistically significant and economically meaningful. In particular, we find a strong network effect. The presence of country nationals at destination tends to act as a magnet for international students. Interestingly, this effect is found to increase with the level of education of the network at destination. The higher the level of education of migrants already present in the host country, the higher the flow of students of the same nationality. The effects of diaspora outweigh the traditional role of previous colonial ties. Students tend to move more to former colonizer, not explicitly for these direct colonial ties, 
but because the can rely on people from their origin country ( these colonial ties explain the arrival of the latter). This network effect, not present in the existing literature, is nevertheless an important factor. This impact is equivalent to a reduction in living costs in he host countries between $40 \%$ and $55 \%$.

The estimation of the impact of destination specific factors also yields striking results. Students, in their location choice, are sensitive to the wage and to the quality of higher education at destination (which is consistent with our human capital approach), to the living costs an host capacity (which are important attractiveness variables). The quality of education, a proxi of academic excellence premium in our theoretical model, is significant but appears to be a moderate attractor for international students. Furthermore, in contrast with living costs, education fees do not seem to act purely as a cost component of foreign education. We find some support for a signaling effect of quality for fees. This might be explained by the fact that fees are very often covered by grants benefiting to international students. Integration of data on grants to international students would be a desirable extension of this work to dig further into this interpretation. Another complementary explanation is that countries with high reputation universities can afford to raise fees as the demand exceeds the number of vacant slots. Our instrumental variable estimation also supports this interpretation.

These results are not without relevance for migration policy. What policy instruments are available to governments in an international environment where competition is tough when trying to attract students in mobility? It's beyond the realms of possibility for any policy to try to change the variables affecting the migration costs (language, ...). Even the composition and the size of diaspora, which are important factors, are proving difficult to change in the medium term. Moreover, this would have effects not only on students flows, but also on many others aspects of migration. Undeniably, our results show that an attractiveness policy should pay special attention to reducing the costs at destination, and is all the more effective when it reduces the living costs rather than the fees. 


\section{REFERENCES}

Agasisti, T. and Dal Bianco, A. (2007). Determinants of college student migration in Italy: Empirical evidence from a gravity approach. Working paper.

Anderson and van Wincoop, E. (2004). Trade costs. Journal of Economic Literature, 42(3):691751.

Aslangbengui, N. and Montecinos, V. (1998). Foreign students in US doctoral programs. The Journal of Economic Perspectives, 12(3):171-182.

Baryla, J. E. and Dotterweich, D. (2001). Student migration: do significant factors vary by region? Education Economics, 9(3):269-80.

Becker, G. (1964). Human capital: a theoretical and empirical analysis with special reference to education. New York: Columbia University Press.

Beine, M., Docquier, F., and Ozden, C. (2011). Diasporas. Journal of Development Economics, 95(3):30-42.

Beine, M., Docquier, F., and Rapoport, H. (2008). Brain drain and human capital formation in developing countries: Winners and losers. Economic Journal, 118:631-652.

Bessey, D. (2007). International student migration to Germany. Swiss Leading House Working Paper, 6.

Borjas, G. (2004). Do foreign students crowd out native students from graduate programs? Working Paper, 10349.

Bratsberg, B. (1995). The incidence of non-return among foreign students in the United States. Economics of Education Review, 14(4):373-384.

Card, D. and Krueger, A. (1992). Does school quality matter? Returns to education and the characteristics of public school in United States. Journal of Political economy, 100(1):1-40.

Chiswick, B. (1978). The effect of americanization on the earnings of foreign born men. Journal of Political Economy, 86:897-922.

Cummings, W. (1984). Going overseas for higher education: the asian experience. Comparative Education Review, 28(2):241-257.

Docquier, F. and Rapoport, H. (2011). Globalization, brain drain and development. Journal of Economic Literature, forthcoming.

Dreher, A. and Poutvaara, P. (2005). Student flows and migration: an empirical analysis. CESifo Working Paper.

Finn, M. (2003). Stay rates of foreign doctorate recipients from US universities. Oak Ridge Institute for Science and Education.

Freeman, R. (1971). The market for college-trained manpower. Cambridge, MA: Harvard University Press.

Gordon, J. and Jallade, J.-P. (1996). "Spontaneous" student mobility in the European Union: a statistical survey. European journal of education, 31(2):133-151. 
Grogger, J. and Hanson, G. (2011). Income maximisation and the selection and sorting of international migrants. Journal of Development Economics, 95(1):42-57.

Hanushek, E. and Hanson, D. (2000). Schooling, labor force quality, and the growth of nations. American Economic Review, 90(5):1184-1204.

Haupt, A., Krieger, T., and Lange, T. (2010). A note on brain gain and brain drain: permanent migration and education policy. CESifo Working Paper Series $n 3154$.

IEE (2010). Open Doors 2010: Report on International Educational Exchange. Institute of International Education.

Kjellstrom, C. and Regner, H. (1998). Does distance to a university affect enrollement decisions? Evidence from data on three cohorts of Swedes. Institute for Social Research, Stockholm University, Stockholm, 8/98.

Manski, C. (1993). Identification and endogeneous social effects : the reflection problem. Review of Economic Studies, 60(3):531-42.

McCann, P. and Sheppard, S. (2001). Public investment and regional labour markets: the role of UK higher institutions. In Public Investment and Regional Economic Development : Essays in Honour of Moss Madden, volume forthcoming. Edward Elgar Publishing, Cheltenham.

McFadden, D. (1981). Structural Analysis of Discrete Data with Econometric Applications, chapter Econometric Models of Probabilistic Choice. Cambridge.

McKenzie, D. and Rapoport, H. (2011). Can immigration reduce educational attainment? evidence from mexico. Journal of Population Economics.

McMahon, M. (1992). Higher education in a world market. An historical look at a global context of international study. Higher Education, 24(4):465-482.

Mixon, F. J. (1992a). Factors affecting college student migration across states. International Journal of Manpower, 13(1):25-32.

Mixon, F. J. (1992b). A public choice note on college student migration. International Journal of Manpower, 13(3):63-68.

Mixon, F. J. and Hsing, Y. (1994a). College student migration and human capital theory: a research note. Education Economics, 2(1):65-73.

Mixon, F. J. and Hsing, Y. (1994b). The determinants of out-of-state enrollments in higher education: a tobit analysis. Economics of Education Review, 13(4):329-335.

OECD (2006). Education at a Glance. OECD Indicators.

OECD (2007). Education at a Glance. OECD Indicators.

OECD (2009a). International Migration Outlook. SOPEMI 2009, OECD Paris.

OECD (2009b). International Mobility of the Highly Skilled. OECD, Paris.

OECD (2010). International Migration Outlook. SOPEMI 2010, OECD.

Ono, H. (2001). Migration patterns among Japanese university students. In Paper Presented at the Center for Economic Policy Research Conference of the European Network on Japanese 
Economy, Oxford.

Perkins, R. and Neumayer, E. (2012). Geographies of educational mobilities: exploring unevenness, difference and changes in international studant flows. Working paper, London School of Economics.

Psacharopoulos, G. and Patrinos, H. (2002). Returns to investment in education: a further update. Policy Research Working Paper, 2881:36.

Rosenzweig, M. (2006). Global wage differences and international student flows. Brookings Trade Forum, pages 57-96.

Rosenzweig, M. (2008). Higher education and international migration in Asia: Brain circulation. In Annual World Bank Conference on Development Economics, pages 59-100.

Sa, C., Florax, R., and Rietvield, P. (2004). Determinants of the regional demand for higher education in the Netherlands: a gravity model approach. Regional Studies, 38(4):375-392.

Santos Silva, J. and Tenreyro, S. (2006). The log of gavity. Review of Economics and Statistics, 88 (4):641-658.

Spilimbergo, A. (2009). Democracy and foreign education. American Economic Review, 99 (1):528-43.

Szelenyi, K. (2006). Student without borders? Migratory decision-making among international graduate students in the US. Knowledge, Technology \& Policy, 19(3):64-86.

Tenreyro, S. (2007). On the trade impact of nominal exchange rate volatility. Journal of Development Economics, 82 (2):485-508.

Thissen, L. and Ederveen, S. (2006). Higher education : Time for coordination on a European level. CPB Discussion Paper, 68.

Usher, A. and Cervenan, A. (2005). Global Higher Education Rankings 2005. Toronto on : Educational policy institute.

Van Bouwel, L. (2009). Does university quality drive international student flows? Paper presented at the summer conference, CBS - Copenhagen Business School. 


\section{APPENDIX}

APPEndix1: DATA 


\begin{tabular}{|c|c|c|c|}
\hline 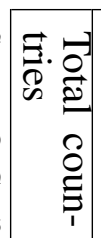 & & 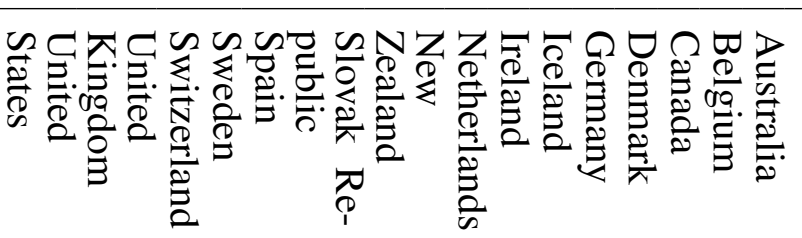 & 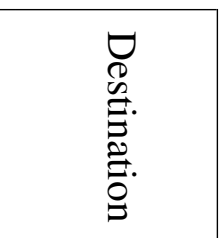 \\
\hline 5 & 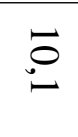 & 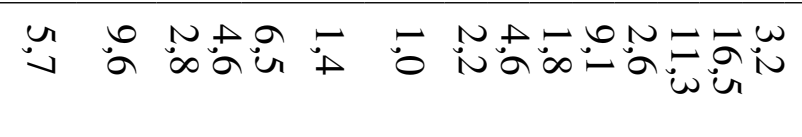 & 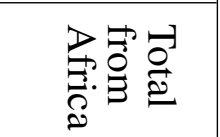 \\
\hline $\begin{array}{l}\vec{b} \\
\dot{b} \\
b\end{array}$ & $\begin{array}{l}+ \\
\infty \\
\dot{0}\end{array}$ & 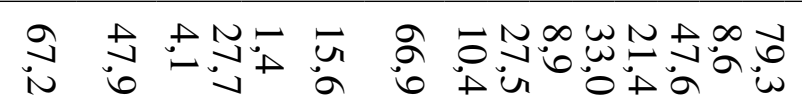 & 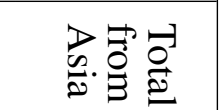 \\
\hline$\underbrace{N}_{0}$ & $\stackrel{n}{+\infty}$ & 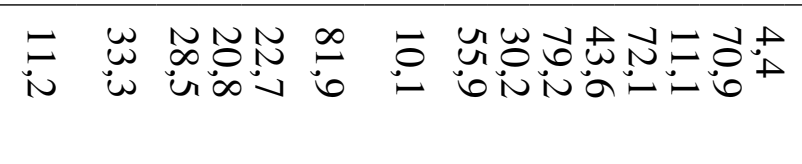 & 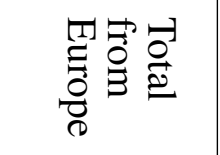 \\
\hline$\omega$ & $\stackrel{\omega}{\sim}$ & 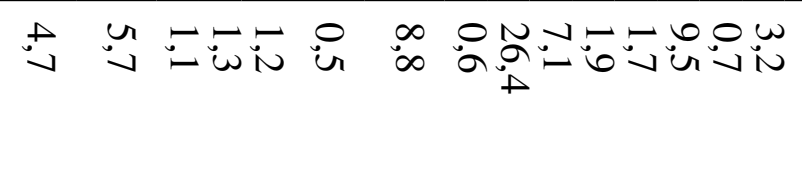 & 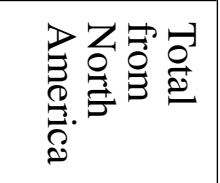 \\
\hline 5 & $\stackrel{\infty}{\infty}$ & 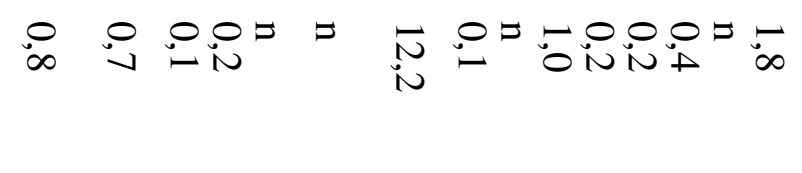 & 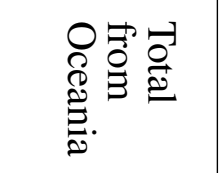 \\
\hline 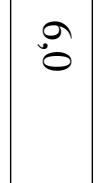 & $\ddot{w}$ & 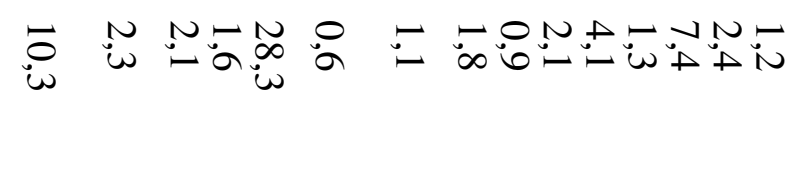 & 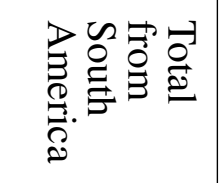 \\
\hline$\dddot{\omega}$ & $\stackrel{\infty}{\infty}$ & 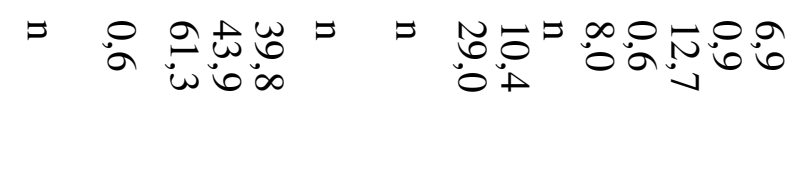 & 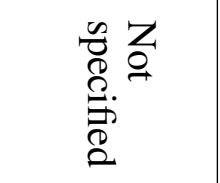 \\
\hline $\overrightarrow{8}$ & $\overline{8}$ & $\overrightarrow{8} \overrightarrow{8} \overrightarrow{8} \overrightarrow{8} \overrightarrow{8} \overline{8} \overrightarrow{8} \overrightarrow{8} \overrightarrow{8} \overrightarrow{8} \overrightarrow{8} \overrightarrow{8}$ & 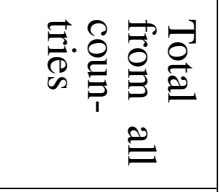 \\
\hline 岕 & $\stackrel{\omega}{\circ}$ & 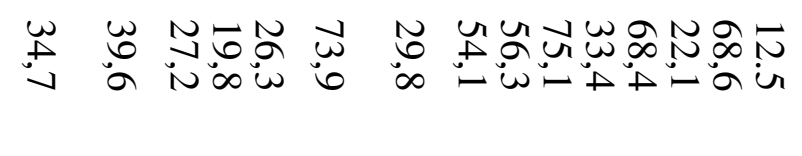 & 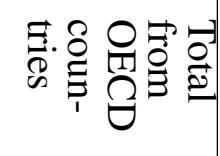 \\
\hline
\end{tabular}


Table 8 - Students in mobility compared to the flows of foreign workers (2007)

\begin{tabular}{|c|c|c|c|c|c|}
\hline Destination & $\begin{array}{l}\text { Students } \\
\text { in mo- } \\
\text { bility as } \\
\text { a \% of } \\
\text { total en- } \\
\text { rolment }\end{array}$ & $\begin{array}{l}\text { Per } 1000 \\
\text { popula- } \\
\text { tion }\end{array}$ & $\begin{array}{l}\text { Interna } \\
\text {-tional } \\
\text { students } \\
\text { (stock) } \\
\text { (1) }\end{array}$ & $\begin{array}{l}\text { Inflows } \\
\text { of } \\
\text { foreign- } \\
\text { born } \\
\text { labour } \\
\text { (2) }\end{array}$ & $(1) /(2)$ \\
\hline Australia & 19,5 & 10,1 & 211500 & 148100 & 1,43 \\
\hline Austria & 12,4 & 3,9 & 32400 & 29600 & 1,09 \\
\hline Belgium & 7,5 & 2,4 & 25200 & 23000 & 1,10 \\
\hline Canada & 7,7 & 2,1 & 68500 & 164900 & 0,42 \\
\hline Denmark & 5,5 & 2,3 & 12700 & 17200 & 0,74 \\
\hline Finland & 4,1 & 2,4 & 12700 & 23000 & 0,55 \\
\hline Germany & - & 2,5 & 206900 & 380300 & 0,54 \\
\hline Ireland & 8,8 & 4 & 16800 & 23600 & 0,71 \\
\hline Japan & 2,9 & 0,9 & 115100 & 77900 & 1,48 \\
\hline Netherlands & 4,7 & 1,7 & 27400 & 50000 & 0,55 \\
\hline $\begin{array}{l}\text { New } \\
\text { Zealand }\end{array}$ & 13,6 & 7,8 & 33000 & 12400 & 2,66 \\
\hline Norway & 2,2 & 1 & 4800 & 54800 & 0,09 \\
\hline Spain & 1,8 & 0,7 & 32300 & 102500 & 0,32 \\
\hline Switzerland & 14 & 2,4 & 29800 & 74300 & 0,40 \\
\hline $\begin{array}{l}\text { United } \\
\text { Kingdom }\end{array}$ & 14,9 & 5,8 & 351500 & 88000 & 3,99 \\
\hline $\begin{array}{l}\text { United } \\
\text { States }\end{array}$ & 3,4 & 2 & 595900 & 666100 & 0,89 \\
\hline
\end{tabular}


Table 9 - Category of students and criterion used (by country)

\begin{tabular}{|c|c|}
\hline \multicolumn{2}{|c|}{ Category of students and criterion used } \\
\hline & International students \\
\hline $\begin{array}{l}\text { Australia } \\
\text { Belgium } \\
\text { Canada } \\
\text { Denmark } \\
\text { New Zealand } \\
\text { Slovak Repub- } \\
\text { lic } \\
\text { Spain } \\
\text { Sweden } \\
\text { United King- } \\
\text { dom } \\
\text { United States } \\
\text { Germany } \\
\text { Ireland } \\
\text { Netherlands } \\
\text { Switzerland }\end{array}$ & $\begin{array}{l}\text { Non-resident students of reporting country } \\
\text { Non-resident students of reporting country } \\
\text { Non-resident students of reporting country } \\
\text { Non-resident students of reporting country } \\
\text { Non-resident students of reporting country } \\
\text { Non-resident students of reporting country } \\
\text { Non-resident students of reporting country } \\
\text { Non-resident students of reporting country } \\
\text { Non-resident students of reporting country } \\
\text { Non-resident students of reporting country } \\
\text { Students with prior education outside the re- } \\
\text { porting country } \\
\text { Students with prior education outside the re- } \\
\text { porting country } \\
\text { Students with prior education outside the re- } \\
\text { porting country and non-resident of the report- } \\
\text { ing country since } 2005 \\
\text { Students with prior education outside the re- } \\
\text { porting country }\end{array}$ \\
\hline \multicolumn{2}{|c|}{ Foreign students (non-citizen students of reporting country) } \\
\hline & $\begin{array}{c}\text { Austria } \\
\text { Czech Republic } \\
\text { Finland } \\
\text { France } \\
\text { Greece } \\
\text { Hungary } \\
\text { Iceland } \\
\text { Italy } \\
\text { Japan } \\
\text { Korea } \\
\text { Luxembourg } \\
\text { Norway } \\
\text { Poland } \\
\text { Portugal } \\
\text { Turkey }\end{array}$ \\
\hline
\end{tabular}


Table 10 - International students versus foreign students (2007)

\begin{tabular}{|l||c|c|c|}
\hline Destination & International students (1) & Foreign students (2) & $(1) /(2)$ \\
\hline & & & \\
Australia & 211500 & 244300 & 0,87 \\
Austria & 32400 & 43600 & 0,74 \\
Belgium & 25200 & 41400 & 0,61 \\
Canada & 68500 & 132200 & 0,52 \\
Denmark & 12700 & 20900 & 0,61 \\
Finland & 12700 & 258500 & 1,26 \\
Germany & 206900 & - & 0,80 \\
Ireland & 16800 & 125900 & - \\
Japan & 115100 & 37600 & 0,91 \\
Netherland & 27400 & 65000 & 0,73 \\
New Zealand & 33000 & 15600 & 0,31 \\
Norway & 4800 & 41100 & 0,54 \\
Spain & 32300 & 460000 & 0,73 \\
Switzerland & 29800 & - & 0,76 \\
United Kingdom & 351500 & - & - \\
United States & 595900 & \multicolumn{2}{|c|}{} \\
\hline \multicolumn{2}{|r|}{ Mean } & - &
\end{tabular}




\section{APPENDix2: Alternative estimation Methods}

Table 11 - Bilateral determinants: alternative regression methods

\begin{tabular}{|c|c|c|c|c|c|c|c|c|}
\hline \multirow{3}{*}{$\begin{array}{l}\text { Method } \\
\text { Variables }\end{array}$} & \multicolumn{4}{|c|}{ Total network } & \multicolumn{4}{|c|}{ Skilled network } \\
\hline & (OLS) & $(\mathrm{OLS})$ & (Heckman) & (Tobit) & $(\mathrm{OLS})$ & $(\mathrm{OLS})$ & (Heckman) & (Tobit) \\
\hline & (2) & (3) & (4) & (5) & (6) & (7) & (8) & (9) \\
\hline Constant & $5.386 * * *$ & $9.568 * * *$ & $12.259 * * *$ & $13.063 * * *$ & $12.259 * * *$ & $7.901 * * *$ & $11.595 * * *$ & $12.432 * * *$ \\
\hline Distance & $\begin{array}{c}-0.874 * * * \\
(0.055)\end{array}$ & $\begin{array}{c}-0.728 * * * \\
(0.049)\end{array}$ & $\begin{array}{c}-0.866^{* * *} * \\
(0.050)\end{array}$ & $\begin{array}{c}-0.919 * * * \\
(0.054)\end{array}$ & $\begin{array}{c}-0.698 * * * \\
(0.055)\end{array}$ & $\begin{array}{c}-0.587 * * * \\
(0.048)\end{array}$ & $\begin{array}{c}-0.839 * * * \\
(0.050)\end{array}$ & $\begin{array}{c}-0.894 * * * \\
(0.053)\end{array}$ \\
\hline Colony & $\begin{array}{c}0.792 * * * \\
(0.139)\end{array}$ & $\begin{array}{c}0.671 * * * \\
(0.144)\end{array}$ & $\begin{array}{c}0.800 * * * \\
(0.134)\end{array}$ & $\begin{array}{c}0.794 * * * \\
(0.137)\end{array}$ & $\begin{array}{c}0.716^{* * * *} \\
(0.137)\end{array}$ & $\begin{array}{c}0.571 * * * \\
(0.141)\end{array}$ & $\begin{array}{c}0.722 * * * \\
(0.132)\end{array}$ & $\begin{array}{c}0.717 * * * \\
(0.135)\end{array}$ \\
\hline Language & $\begin{array}{c}0.859 * * * \\
(0.101)\end{array}$ & $\begin{array}{c}0.612 * * * \\
(0.086)\end{array}$ & $\begin{array}{c}0.784 * * * \\
(0.091)\end{array}$ & $\begin{array}{c}0.913 * * * \\
(0.097)\end{array}$ & $\begin{array}{c}1.130 * * * \\
(0.166)\end{array}$ & $\begin{array}{c}1.007 * * * \\
(0.194)\end{array}$ & $\begin{array}{c}0.856 * * * \\
(0.091)\end{array}$ & $\begin{array}{c}0.830 * * * \\
(0.097)\end{array}$ \\
\hline Network & $\begin{array}{c}0.236 * * * \\
(0.018)\end{array}$ & $\begin{array}{c}0.224 * * * \\
(0.015)\end{array}$ & $\begin{array}{c}0.256 * * * \\
(0.015)\end{array}$ & $\begin{array}{c}0.243 * * * \\
(0.018)\end{array}$ & $\begin{array}{c}0.299 * * * \\
(0.021)\end{array}$ & $\begin{array}{c}0.406^{* * * *} \\
(0.018)\end{array}$ & $\begin{array}{c}0.317 * * * \\
(0.017)\end{array}$ & $\begin{array}{c}0.304 * * * \\
(0.020)\end{array}$ \\
\hline \# obs & 1929 & 2444 & 2444 & 2444 & 1929 & 2442 & 2444 & 2444 \\
\hline \# orig c & 203 & 203 & 203 & 203 & 203 & 203 & 203 & 203 \\
\hline \# dest c & 13 & 13 & 13 & 13 & 13 & 13 & 13 & 13 \\
\hline$R^{2}$ & 0.811 & 0.835 & - & 0.398 & 0.812 & 0.841 & - & 0.402 \\
\hline Orig FE & yes & yes & yes & yes & yes & yes & yes & yes \\
\hline Dest FE & yes & yes & yes & yes & yes & yes & yes & yes \\
\hline
\end{tabular}

$*, * *$ and $* * *$ denote significance at the 10,5 and $1 \%$ significance levels.

For all regressions, network refers to the stock of migrants observed in 2000.

Columns (2) and (6): dependent variable: $\log$ of number of students

Columns (3) and (7): dependent variable: $\log$ of (number of students+1) 
Table 12 - Destination specific determinants: alternative regression methods

\begin{tabular}{|c|c|c|c|c|c|c|c|c|}
\hline \multirow{3}{*}{$\begin{array}{l}\text { Method } \\
\text { Variables }\end{array}$} & \multicolumn{4}{|c|}{ Total network } & \multicolumn{4}{|c|}{ Skilled network } \\
\hline & (OLS) & $(\mathrm{OLS})$ & (Heckman) & (Tobit) & (OLS) & $(\mathrm{OLS})$ & (Heckman) & (Tobit) \\
\hline & $(2)$ & (3) & (4) & $(5)$ & $(6)$ & (7) & (8) & (9) \\
\hline Constant & $\begin{array}{c}15.059^{* * *} \\
(2.450)\end{array}$ & $\begin{array}{c}9.360 * * * \\
(2.018)\end{array}$ & $\begin{array}{c}12.742 * * * \\
(2.748)\end{array}$ & $\begin{array}{l}12.365 \\
(2.206)\end{array}$ & $\begin{array}{c}12.819^{* * * *} \\
(2.387)\end{array}$ & $\begin{array}{c}6.642 * * * \\
(1.949)\end{array}$ & $\begin{array}{c}10.715^{* * *} \\
(2.429)\end{array}$ & $\begin{array}{c}10.182^{* * * *} \\
(2.186)\end{array}$ \\
\hline Distance & $\begin{array}{c}-0.874 * * * \\
(0.055)\end{array}$ & $\begin{array}{c}-0.466^{* * *} \\
(0.051)\end{array}$ & $\begin{array}{c}-0.650 * * * \\
(0.059)\end{array}$ & $\begin{array}{c}-0.756^{* * *} \\
(0.054)\end{array}$ & $\begin{array}{c}-0.572 * * * \\
(0.052)\end{array}$ & $\begin{array}{c}-0.472 * * * \\
(0.048)\end{array}$ & $\begin{array}{c}-0.651 * * * \\
(0.052)\end{array}$ & $\begin{array}{c}-0.756 * * * \\
(0.052)\end{array}$ \\
\hline Colony & $\begin{array}{c}0.792 * * * \\
(0.139)\end{array}$ & $\begin{array}{c}0.668 * * * \\
(0.148)\end{array}$ & $\begin{array}{c}0.641 * * * \\
(0.173)\end{array}$ & $\begin{array}{c}0.780 * * * \\
(0.136)\end{array}$ & $\begin{array}{c}0.618 * * * \\
(0.137)\end{array}$ & $\begin{array}{c}0.667 * * * \\
(0.142)\end{array}$ & $\begin{array}{c}0.666 * * * \\
(0.152)\end{array}$ & $\begin{array}{c}0.789 * * * \\
(0.134)\end{array}$ \\
\hline Language & $\begin{array}{c}1.125 * * * \\
(0.125)\end{array}$ & $\begin{array}{c}0.885 * * * \\
(0.095)\end{array}$ & $\begin{array}{c}1.300 * * * \\
(0.123)\end{array}$ & $\begin{array}{c}1.366^{* * * *} \\
(0.110)\end{array}$ & $\begin{array}{c}1.337 * * * \\
(0.121)\end{array}$ & $\begin{array}{c}0.979 * * * \\
(0.115)\end{array}$ & $\begin{array}{c}0.745 * * * \\
(0.092)\end{array}$ & $\begin{array}{c}1.190 * * * \\
(0.111)\end{array}$ \\
\hline Network & $\begin{array}{c}0.327 * * * \\
(0.019)\end{array}$ & $\begin{array}{c}0.310 * * * \\
(0.016)\end{array}$ & $\begin{array}{c}0.388 * * * \\
(0.020)\end{array}$ & $\begin{array}{c}0.235 * * * \\
(0.020)\end{array}$ & $\begin{array}{c}0.396 * * * \\
(0.020)\end{array}$ & $\begin{array}{c}0.396 * * * \\
(0.020)\end{array}$ & $\begin{array}{c}0.459 * * * \\
(0.019)\end{array}$ & $\begin{array}{c}0.311 * * * \\
(0.022)\end{array}$ \\
\hline Population & $\begin{array}{l}-0.019 \\
(0.070)\end{array}$ & $\begin{array}{c}0.040 \\
(0.055)\end{array}$ & $\begin{array}{l}-0.090 \\
(0.075)\end{array}$ & $\begin{array}{l}-0.020 \\
(0.068)\end{array}$ & $\begin{array}{l}-0.005 \\
(0.068)\end{array}$ & $\begin{array}{c}0.036 \\
(0.052)\end{array}$ & $\begin{array}{c}-0.058 \\
(0.065)\end{array}$ & $\begin{array}{c}-0.043 \\
(0.065)\end{array}$ \\
\hline Ranking & $\begin{array}{l}-0.016 \\
(0.119)\end{array}$ & $\begin{array}{l}-0.131 \\
(0.089)\end{array}$ & $\begin{array}{l}-0.162 \\
(0.122)\end{array}$ & $\begin{array}{c}-0.187 * \\
(0.109)\end{array}$ & $\begin{array}{l}-0.043 \\
(0.116)\end{array}$ & $\begin{array}{c}-0.182 * * \\
(0.085)\end{array}$ & $\begin{array}{l}-0.160 \\
(0.111)\end{array}$ & $\begin{array}{c}-0.252^{* *} * \\
(0.106)\end{array}$ \\
\hline Living cost & $\begin{array}{c}-6.473 * * * \\
(0.499)\end{array}$ & $\begin{array}{c}-5.381 * * * \\
(0.418)\end{array}$ & $\begin{array}{c}-7.127 * * * \\
(0.543)\end{array}$ & $\begin{array}{c}-6.881 * * * \\
(0.442)\end{array}$ & $\begin{array}{c}-5.542 * * * \\
(0.791)\end{array}$ & $\begin{array}{c}-4.359 * * * \\
(0.400)\end{array}$ & $\begin{array}{c}-5.855^{* * *} \\
(0.480)\end{array}$ & $\begin{array}{c}-6.093 * * * \\
(0.429)\end{array}$ \\
\hline Fees & $\begin{array}{c}-0.047 * * \\
(0.019)\end{array}$ & $\begin{array}{c}-0.028 * * \\
(0.014)\end{array}$ & $\begin{array}{l}-0.025 \\
(0.017)\end{array}$ & $\begin{array}{c}0.050 * * * \\
(0.015)\end{array}$ & $\begin{array}{c}-0.042 * * \\
(0.019)\end{array}$ & $\begin{array}{l}-0.020 \\
(0.013)\end{array}$ & $\begin{array}{l}-0.019 \\
(0.015)\end{array}$ & $\begin{array}{c}0.050 * * * \\
(0.019)\end{array}$ \\
\hline Wages & $\begin{array}{c}4.841 * * * \\
(0.341)\end{array}$ & $\begin{array}{c}4.397 * * * \\
(0.259)\end{array}$ & $\begin{array}{c}5.669 * * * \\
(0.366)\end{array}$ & $\begin{array}{c}5.805 * * * \\
(0.298)\end{array}$ & $\begin{array}{c}4.158 * * * \\
(0.337)\end{array}$ & $\begin{array}{c}3.769 * * * \\
(0.254)\end{array}$ & $\begin{array}{c}4.764 * * * \\
(0.319)\end{array}$ & $\begin{array}{c}5.291 * * * \\
(0.292)\end{array}$ \\
\hline \# obs & 1455 & 1880 & 1880 & 1880 & 1455 & 1880 & 1880 & 1880 \\
\hline \# orig c & 203 & 203 & 203 & 203 & 203 & 203 & 203 & 203 \\
\hline$R^{2}$ & 0.749 & 0.779 & - & 0.365 & 0.812 & 0.841 & - & 0.372 \\
\hline Orig FE & yes & yes & yes & yes & yes & yes & yes & yes \\
\hline Dest FE & no & no & no & no & no & no & no & no \\
\hline
\end{tabular}

$*, * *$ and $* * *$ denote significance at the 10,5 and $1 \%$ significance levels.

For all regressions, network refers to the stock of migrants observed in 2000.

Columns (2) and (6): dependent variable: $\log$ of number of students

Columns (3) and (7): dependent variable: $\log$ of (number of students+1) 